\title{
Synthesis, Biological evaluation, Quantum Chemical Calculations, Molecular Docking and Effect of High Energetic Gamma Irradiation on $\mathrm{Cu}(\mathrm{I}, \mathrm{II}), \mathrm{Zn}(\mathrm{II})$ and Cd(II) Complexes.
}

Hussein Elganzory ( $\sim$ hhsien@qu.edu.sa )

Qassim University College of Science https://orcid.org/0000-0002-9426-5434

Research Article

Keywords: Thiosemicarbazide, Complexes, Irradiation, DFT,囚X_ray, Docking, Antibacterial, Thermal

Posted Date: September 13th, 2021

DOl: https://doi.org/10.21203/rs.3.rs-836470/v2

License: (ㅇ) (i) This work is licensed under a Creative Commons Attribution 4.0 International License. Read Full License 


\section{Abstract}

Novel complexes of $\mathrm{Cu}(\mathrm{I}, \mathrm{II}), \mathrm{Zn}(\mathrm{II})$ and $\mathrm{Cd}(\mathrm{II})$ of thiosemicarbazide ligand $\left(\mathrm{H}_{2} \mathrm{~L}_{\mathrm{B}}\right)$ have been prepared and characterized. The results confirmed that gamma ray enhanced the stability of irradiated compounds as compared to non-irradiated. XRD patterns proved that increasing the crystallinity of particles in nano range after gamma irradiation. Data obtained indicated that the $\mathrm{Cu}(\mathrm{I})$ and $\mathrm{Cd}(\mathrm{II})$ ions coordinated to the ligand through the $(\mathrm{C}=\mathrm{O}), \mathrm{N}(2) \mathrm{H}$ and $(\mathrm{C}=\mathrm{S})$, (neutral tridentate ligand). While, $\mathrm{Cu}(\mathrm{II})$ and $\mathrm{Zn}(\mathrm{II})$ complexes the ligand behaves as neutral tetradentate and coordination take place via $(\mathrm{C}=0)$ and two $\mathrm{N}(2) \mathrm{H}$. These studies revealed that, two kinds of stereochemical geometries; $\mathrm{Cu}(\mathrm{II})$ and $\mathrm{Zn}(\mathrm{II})$ complexes were predicted to be octahedral, $\mathrm{Cu}(\mathrm{I})$ and $\mathrm{Cd}(\mathrm{II})$ complexes were found to be tetrahedral. The theoretical conformational structure analyses were performed using DFT at B3LYP functional with 6-31G(++)d,p basis set for ligand and LANL2DZ basis set for complexes. The inhibitory effect on the growth against gram-positive and gram-negative bacteria of prepared complexes have been tested. Results suggested that $1 \mu \mathrm{g} / \mathrm{ml}$ and $5 \mu \mathrm{g} / \mathrm{ml}$ for $\mathrm{Cu}(\mathrm{II})$ and $\mathrm{Zn}$ (II) complexes have higher activity than other complexes. The chelation could facilitate the ability to cross the cell membrane of $E$. coli. Molecular docking investigation proved that; the $\mathrm{Zn}(\mathrm{II})$ complex has interesting interactions with active site amino acids of topoisomerase II DNA gyrase enzymes (code: 2 XCT).

\section{Introduction}

Thiosemicarbazones are compounds which have increased importance over the decades as prospective medicine candidates. When coordinated to elements, they have evidenced as good antitumour, antimicrobial, antioxidant and antiprotozoal managers. Transition element created complexes hold several advantages over other metal chelated because of their good acceptability and decrease toxicity in living organisms [1]. Thiosemicarbazone compound are of diverse importance for the reason that of their useful for living and pharmacological activities. Thiosemicarbazone derivatives have found application in drug development for the treatment of central nervous system disorders, of bacterial infection, as well as analgesic and antiallergic agent. Thiosemicarbazones are potent intermediates for the synthesis of pharmaceutical and bioactive materials and thus, they are used extensively in the field of medicinal chemistry. Moreover, thiosemicarbazones have found their way into almost every branch of chemistry; commercially they are used as dyes, photographic films, plastic and in textile industry [2] The biological activity of these compounds depends upon the starting materials and their reaction conditions, also related to molecular conformation in particular, which can also be significantly affected by the presence of intra- and intermolecular hydrogen bonding [3]. Thiosemicarbazones commonly performance such as chelating compound for metal ions, attachment through $(\mathrm{C}=\mathrm{S})$ and $(\mathrm{C}=\mathrm{N}-)$ groups, although in several cases they behave as mono dentate compound where they bind through $(\mathrm{C}=\mathrm{S})$ only [4]. A series of copper(II) complexes of 2- phenylamino acetyl-N-phenyl hydrazine carbthioamide $\left(\mathrm{H}_{2} \mathrm{~L}\right)$ have been prepared and characterized by chemical and physical studies. The thermal behaviors of these chelates before and after $y$-irradiation show that the complexes have induced more thermal stability after $\gamma$-irradiation. Solid state dc electrical conductivity for complexes was investigated before and after $\mathrm{Y}$ - irradiation [5,6]. Recently, complexes of $\mathrm{VO}^{2+}, \mathrm{Mn}^{2+}, \mathrm{Zn}^{2+}, \mathrm{Ru}^{3+}, \mathrm{Pd}^{2+}, \mathrm{Ag}^{+}$and $\mathrm{Hg}^{2+}$ have been prepared by reacting their metal salts with ligand, named (4-(4-chlorophenyl)-1-(2-(phenylamino) acetyl) thiosemicarbazone). Structure of synthesized metal complexes was confirmed by different analytical and spectral techniques $\left({ }^{1} \mathrm{H}\right.$ NMR, MS, FT-IR, UV-Vis, EPR and Powder X-ray diffraction), thermogravimetric studies as well as molecular modeling. FT-IR spectra showed that the compound behave as neutral or monobasic tetradentate. In case of 
complexes of $\mathrm{Mn}^{2+}, \mathrm{Zn}^{2+}, \mathrm{Ag}^{+}$and $\mathrm{VO}^{2+}$, through (N2-H), (C=0) or (C-O) groups. X-ray diffraction pattern of $\mathrm{Mn}^{2+}, \mathrm{Pd}^{2+}$ and $\mathrm{Ag}^{+}$complexes before and after irradiation are recorded. XRD studies exhibited that decrease in the crystalline size of sample $\mathrm{Mn}^{2+}$ as compared of samples $\mathrm{Ag}^{+}$and $\mathrm{Pd}^{2+}$ upon irradiation and irradiation influenced the crystallinity of the complexes. The possible structures of the ligand, $\mathrm{Mn}^{2+}, \mathrm{Pd}^{2+}$ and $\mathrm{Hg}^{2+}$ complexes have been computed by means of the molecular mechanic calculations using the hyper chem. 8.03 molecular modeling program. The effect of gamma irradiation was investigated by recording the new results of pervious spectroscopic techniques and other measurements. The TGA studies of unirradiated and irradiated complexes showed that irradiated complexes were more thermally stable than unirradiated. The compound and its metal complexes have been experienced for their inhibitory outcome on the growth of microorganisms against gram positive and gram negative. The results proved that the complexes $\mathbf{B}_{\mathbf{1}}-\mathbf{B}_{\mathbf{7}}$ have potent antibacterial activity as compared to that of ligand [7-10]. In this work we described the synthesis, characterization, DFT, molecular docking as well as antibacterial activities of $\mathrm{Cu}(\mathrm{I}, \mathrm{II}), \mathrm{Zn}(\mathrm{II})$ and $\mathrm{Cd}(\mathrm{II})$ of complexes of ligand 1-(p- (methylanilinocetyl-4-phenyl-thiosemicarbazide) $\left(\mathrm{H}_{2} \mathrm{~L}_{B}\right)$.

\section{Materials And Methods}

\subsection{Materials}

All chemicals used in this study were of analytically reagent grade, commercially available from Fulka and used without previous purification as $\mathrm{Cul}$ (anhydrous), $\mathrm{Cu}\left(\mathrm{ClO}_{4}\right)_{2} \cdot 3 \mathrm{H}_{2} \mathrm{O}, \mathrm{ZnCl}_{2} \cdot 3 \mathrm{H}_{2} \mathrm{O}$ compounds which represent the metal ions used in and $\mathrm{CdCl}_{2}$ (anhydrous), complexation process. All solvents were used as it is without previous purifications.

\subsection{Synthesis of thiosemicarbazide ligand $\left(\mathrm{H}_{2} \mathrm{~L}_{B}\right)$}

The organic ligand 1-(p-(methylanilinocetyl-4-phenyl-thiosemicarbazide) $\left(\mathrm{H}_{2} \mathrm{~L}_{B}\right)$ was prepared by mixing equimolar amount of desired hydrazide $(0.01 \mathrm{~mol})$ in $10 \mathrm{ml}$ of absolute ethanol and the appropriate amount of phenyl isothiocynate in $10 \mathrm{ml}$ of absolute $\mathrm{EtOH}$. The reaction mixture was reflux for $6 \mathrm{hrs}$. After cooling, the resulting precipitate was filtered off, washed several times with ethanol and diethyl ether and dried in vacuum in presence of $\mathrm{P}_{4} \mathrm{O}_{10}$.

\subsection{Synthesis of metal complexes}

The metal complexes were prepared by adding to hot absolute ethanol solution $(\sim 20 \mathrm{~mL}) \mathrm{MX}_{2} \cdot \mathrm{nH}_{2} \mathrm{O}$ where $\mathrm{M}=$ $\mathrm{Cu}\left(\mathrm{I}\right.$ and II), $\mathrm{Zn}(\mathrm{II}), \mathrm{Cd}(\mathrm{II})$, and $\mathrm{X}=\mathrm{I}^{-}, \mathrm{ClO}_{4^{-}}, \mathrm{SO}_{4}^{-}$and $\mathrm{Cl}^{-},-, \mathrm{n}=0-1$ in appropriate molar ratio. The resulting mixture was magnetically stirred at $60^{\circ} \mathrm{C}$ for 6-8 $\mathrm{h}$. The formed precipitate was filtered off while hot, otherwise the solution was left at $35^{\circ} \mathrm{C}$ to evaporate some of solvent to promote crystallization. The crystals were collected by vacuum filtrations, washed several times with anhydrous diethyl ether and dried under vacuum in presence of $\mathrm{P}_{4} \mathrm{O}_{10}$.

\subsection{Physical measurements}

Elemental analyses ( $\mathrm{C}, \mathrm{H}$ and $\mathrm{N}$ ) were performed at Microanalytical unit, Cairo University. Metal and halide analyses were estimated using standard literature methods [11]. The Fourier Transform Infrared (FT-IR) 
measurements were performed (4000-400 $\left.\mathrm{cm}^{-1}\right)$ in $\mathrm{KBr}$ discs using Nenexeus-Nicolidite-640-MSA FT-IR, ThermoElectronics Co. The UV-visible absorption spectra were measured in DMF solution using 4802 UV/vis double beam spectrophotometer. The ${ }^{1} \mathrm{H}-\mathrm{NMR}$ spectra have been recorded in DMSO- $\mathrm{d}_{6}$ as a solvent using Varian Gemini 200 NMR spectrophotometer and Varian-Oxford Mercury at $300 \mathrm{MHz}$, respectively.

Thermal analysis (TG/DTG) was obtained out by using a Shimadzu DTA/TG-50 Thermal Analyzer with heating rate of $10^{\circ} \mathrm{C} / \mathrm{min}$ in nitrogen atmosphere with a following rate $20 \mathrm{~mL} / \mathrm{min}$ in the range of ambient temperature up to $800{ }^{\circ} \mathrm{C}$ using platinum crucibles. X-ray powder diffraction analyses of solid samples were measured using APD 2000 PROModel GNR-X-ray Diffractometerat (NRC, Tanta University, Egypt). X-ray diffractograms gives computer control formally finished by PHILIPS $® M P D X ' P E R T$ X-ray diffratometer ready with Cu radiation CuKa $(\lambda=1.54056 \AA)$. The x'pertdiffractometer has the Bragg- Brentano geometry. The x-ray tube used was a copper tube operating at $40 \mathrm{kV}$ and $30 \mathrm{~mA}$. The scanning range $(2 \theta)$ was $5-90^{\circ}$ with step size of $0.050^{\circ}$ and counting time of $2 \mathrm{~s} /$ step. Quartz was used as the standard material to accurate for the instrumental expansion. This identification of the complexes was done by a known method. From the fit identified Scherer formula, the average crystallite size $(D)$ is $D=(K \lambda / \beta \operatorname{Cos} \theta)$

Where: $\lambda$ is the $X$ - ray wavelength in the nanometer, $K$ is factor related to crystallite shape, and with a value about 0.9 and $\beta$ is the peak width at half maximum height. The value of $\beta$ in the $2 \theta$ axis of diffraction shape must be in radians. The $\theta$ is the Bragg angle and be able to in radians since the $\operatorname{Cos} \theta \operatorname{compatible~with~the~same~number.~}$

\subsection{Computational studies}

The input files of ligand and its metal complexes were prepared with GaussView 5.0.8 [12] Gaussian 09 rev. A.02 [13] was used to make the all calculations by the DFT/B3LYP method. 6-31G (++)d, p and LANL2DZ are the standard basis sets for the synthesized ligand and its metal complexes, respectively.

\subsection{Irradiation studies}

For irradiation studies of solid samples of ligand and complexes were subjected to $\boldsymbol{Y}$-irradiation [14] to a dose of 60 kGy using Indian ${ }^{60} \mathrm{Co}$ Y-ray cell type GE-4000 A (at room temperature at the Egyptian Atomic Energy Authority Nasr City, Egypt) at a dose rate of $2.2 \mathrm{kGy} \mathrm{h}^{-1}$. After removing the samples from the radiation field the FT-IR, absorption spectra ,XRD and thermal analysis (TG/DTG) and biological activity of the irradiated samples were investigated by the same methods used for before irradiated compound .

\subsection{Antibacterial activity}

The in vitro antibacterial activity studies were carried out at Genetic Engineering and Biotechnology Research Institute, Department of Microbial Biotechnology at Sadat City University, Egypt, by using Broth Dilution Method $[\mathbf{1 5}, \mathbf{1 6}]$ with some alterations, to investigate the inhibitory effect of some synthesized complexes before $\left(\mathbf{B}_{\mathbf{1}^{-}}\right.$ $\left.\mathbf{B}_{4}\right)$ and after $\left(\mathbf{A}_{1}-\mathbf{A}_{4}\right)$ irradiation on the sensitive organisms Streptococcus pyogenes as Gram- positive bacteria and Escherichia colias Gram-negative bacteria. Nutrient broth medium was prepared by using Brain Heart Infusion (BHI) broth and distilled water. The test compounds in measured quantities were dissolved in DMSO which has no inhibition activity to get two different concentrations $(1 \mathrm{mg} / \mathrm{mL}, 5 \mathrm{mg} / \mathrm{mL})$ of compounds. The strains selected for the study were prepared in (BHI) broth medium with shaking and autoclaved for 20 min 15 pounds of pressure and at $121^{\circ} \mathrm{C}$ before inoculation. The bacteria were then cultured for $24 \mathrm{~h}$ at $37^{\circ} \mathrm{C}$ in an 
incubator. . One $\mathrm{ml}$ of the standard bacterial culture was used as inoculation in a nutrient broth. For growth studies, culture of microbial cells were inoculated and grown aerobically in BHI broth for control and along with various concentrations of the test compounds in individual flasks. Growth was calculated turbidometrically at $650 \mathrm{~nm}$ using conventional Spectrophotometer, in which turbidity produced is measured by taking absorbance and compared with turbidity produced by control. The growth rate of different bacteria in absence as well as in presence of test compounds was performed for each concentration. Absorption measurements were accomplished by spectrophotometer after 24 and $48 \mathrm{~h}$ of incubation to determine the number of viable organisms per milliliter of sample and were used to the calculated the \% inhibition.

\subsection{Molecular docking}

All docking steps were done by MOE 2008 (Molecular Operating Environment) software to simulate the binding model of these compounds into topoisomerase II DNA gyrase enzymes (2XCT). The protein crystal structure was obtained from the Protein Data Bank (PDB).

\section{Results And Discussion}

\subsection{Elemental analysis and molar conductance}

The analytical and physical data of the prepared ligand and metal complexes are collected in Table (1). The chemical composition and stoichiometry of the prepared metal complexes were confirmed by the results of elemental analysis. The obtained data showed satisfactory agreement with the proposed molecular formulae. These data also indicated that the metal complexes have 1:1 (metal: ligand) stoichiometry.

The complexes are found to be air stable for a long time, insoluble in different organic solvents such as (ethanol, methanol, carbon tetrachloride, chloroform, dichloromethane and acetone) but soluble to great extent in DMF and DMSO. Conductivity measurements in non-aqueous solution have frequently been used in structural studies of the prepared metal complexes within the limits of their solubility. The molar conductance values of $10^{-3} \mathrm{M}$ solution of the complexes in DMF are listed in Table (1) show that copper complexes(B1 and B2) are nonelectrolytes in nature [17]. However, complexes $\left(B_{3}, B_{4}\right)$ show molar conductivity values of 72 and $65 \mathrm{ohm}^{-1} \mathrm{~cm}^{2}$ $\mathrm{mol}^{-1}$ indicating 1:2 and 1:1 electrolytic nature in $\operatorname{DMF}\left(10^{-3} \mathrm{~mol} \mathrm{~L}^{-1}\right)$ solution, respectively [18].

Table 1. Elemental analyses and physical properties of ligand (H2LB) and its metal complexes. 


\begin{tabular}{|c|c|c|c|c|c|c|c|c|c|}
\hline \multirow[t]{2}{*}{ No. } & \multirow{2}{*}{$\begin{array}{l}\text { Molecular } \\
\text { formula }\end{array}$} & \multirow{2}{*}{$\begin{array}{l}\text { (Emperical } \\
\text { formulae) }\end{array}$} & \multirow[t]{2}{*}{ M.wt. } & \multirow{2}{*}{$\begin{array}{l}\text { Colour } \\
\text { (Yield } \\
\%)\end{array}$} & \multirow[b]{2}{*}{ C } & \multirow[b]{2}{*}{$\mathrm{H}$} & \multirow[b]{2}{*}{$\mathbf{N}$} & \multirow[b]{2}{*}{$M$} & \multirow[b]{2}{*}{$\Lambda_{\mathrm{m}}$} \\
\hline & & & & & & & & & \\
\hline & $\mathrm{H}_{2} \mathrm{~L}_{\mathrm{B}}$ & $\left(\mathrm{C}_{16} \mathrm{H}_{18} \mathrm{~N}_{4} \mathrm{OS}\right)$ & 314 & Buff & 61.1 & 5.73 & 17.8 & - & - \\
\hline & & & & 75 & (61.3) & $(5.70)$ & (17.9) & & \\
\hline \multirow[t]{2}{*}{$B_{1}$} & $\mathrm{Cu}\left(\mathrm{H}_{2} \mathrm{~L}\right) \mathrm{I}$ & $\left(\mathrm{C}_{16} \mathrm{H}_{18} \mathrm{~N}_{4} \mathrm{OSICu}\right)$ & 504.5 & Green & 38.1 & 3.6 & 11.1 & 12.6 & \\
\hline & & & & 78 & $(38.4)$ & $(4.2)$ & (11.4) & $(12.3)$ & 25 \\
\hline \multirow[t]{2}{*}{$\mathrm{B}_{2}$} & $\mathrm{Cu}\left(\mathrm{H}_{2} \mathrm{~L}\right)_{2}\left(\mathrm{ClO}_{4}\right)_{2}$ & $\left(\mathrm{C}_{32} \mathrm{H}_{36} \mathrm{~N}_{8} \mathrm{O}_{10} \mathrm{~S}_{2} \mathrm{Cl}_{2}\right.$ & 889.5 & Green & 43.2 & 4.0 & 12.6 & 7.1 & \\
\hline & & & & 60 & $(43.8)$ & $(3.78)$ & (12.9) & $(7.6)$ & 24 \\
\hline \multirow[t]{2}{*}{$B_{3}$} & {$[\mathrm{Zn}$} & $\left(\mathrm{C}_{32} \mathrm{H}_{38} \mathrm{~N}_{8} \mathrm{O}_{7} \mathrm{~S}_{2}\right.$ & 807.4 & Yellow & 47.5 & 4.7 & 13.8 & 8.1 & \\
\hline & & $\mathrm{Zn)}$ & & 65 & $(47.2)$ & $(4.9)$ & (13.6) & (8.3) & 72 \\
\hline \multirow[t]{2}{*}{$B_{4}$} & {$\left[\mathrm{Cd}\left(\mathrm{H}_{2} \mathrm{~L}\right) \mathrm{Cl}\right] \mathrm{Cl}$} & $\left(\mathrm{C}_{16} \mathrm{H}_{18} \mathrm{~N}_{4} \mathrm{OSCl}_{2} \mathrm{Cd}\right)$ & 497.4 & White & 38.6 & 3.6 & 11.3 & 22.6 & \\
\hline & & & & 70 & $(39.2)$ & $(4.3)$ & (11.5) & $(23.0)$ & 65 \\
\hline
\end{tabular}

${ }^{\mathbb{m}} \mathrm{m}=$ molar conductivity $\left(\mathrm{ohm}^{-1} \mathrm{~cm}^{2} \mathrm{~mol}^{-1}\right)$ in $10^{-3} \mathrm{M} \mathrm{DMF}$ solution

\subsection{Nuclear magnetic resonance spectroscopy}

The ${ }^{1} \mathrm{H}$ NMR is a helpful tool for the preparation of organic compounds in conjugation with other spectrometric information, nuclear magnetic resonance is a physical phenomenon based upon the magnetic properties of an atom's nucleus.. The most commonly used nuclei are hydrogen ${ }^{1}$ and carbon $^{13}$, although certain isotopes of many other elements nuclei can also be observed. Comparison of the proton nuclear magnetic resonance of 1-(p(methylanilinocetyl-4-phenyl-thiosemicarbazide) ligand before and after $\mathrm{\gamma}$ - irradiation $\left(\mathrm{H}_{2} \mathrm{~L}_{B}\right.$ and $\left.\mathrm{H}_{2} \mathrm{~L}_{A}\right)$ recorded in DMSO- $\mathrm{d}_{6}$ solution is found in (Fig.1). The ${ }^{1} \mathrm{H}$ NMR spectrum of the ligand before $y$ - irradiation $\left(\mathrm{H}_{2} \mathrm{~L}_{B}\right)$ in DMSO- $\mathrm{d}_{6}$ exhibited a chemical shift $(\delta \backslash \mathrm{ppm})=2.5 \mathrm{ppm}$ for $(\mathrm{DMSO})$ before and after $\gamma$-irradiation , the $\mathrm{N}(4) \mathrm{H}$ signal appears with $9.44 \mathrm{ppm}$ and the $\mathrm{N}(2) \mathrm{H}$ signal appears with $9.51,10.05 \mathrm{ppm}$ indicating the involvement of these hydrogen through intra-molecular hydrogen bonding with the carbonyl oxygen, the peak of $\mathrm{N}(1) \mathrm{H}$ appeared at $9.62 \mathrm{ppm}$ for ligand after gamma irradiation. The singlet signal appears with 2.14, 3.9, $3.7 \mathrm{ppm}$ attributed to the protons of methyl $\mathrm{CH}_{3}$, singlet signal appears with $3.7 \mathrm{ppm}$ attributed to the protons of $\mathrm{CH}_{2}$, the multiplet signal appears with $5.85-7.1,6.5-7.4 \mathrm{ppm}$ attributed to the aryl protons. The intensity of the bands after irradiation are higher than before irradiation and some bands disappear upon irradiation $[19,20]$. Also ${ }^{1} \mathrm{H} \mathrm{NMR}$ spectra of $\left[\mathrm{Zn}\left(\mathrm{H}_{2} \mathrm{~L}\right)_{2} \mathrm{SO}_{4}\right]$ before and after p-irradiation $\left(\mathrm{B}_{3}, \mathrm{~A}_{3}\right)$ displayed signals at $2.14\left(\mathrm{~s}, 6 \mathrm{H}, 2 \mathrm{CH}_{3}\right)$, 3.76(s,4H,2 $\left.\mathrm{CH}_{2}\right), 5.59(\mathrm{~s}, 2 \mathrm{H}, 2 \mathrm{NH}), 6.32-7.43(\mathrm{~m}, 18 \mathrm{H}, \mathrm{Ar}-\mathrm{H}), 9.55(\mathrm{~s}, 1 \mathrm{H}, \mathrm{NH})$ and10.51(s, H, NH) as shown in (Fig.2) and. While $\left[\mathrm{Cd}\left(\mathrm{H}_{2} \mathrm{~L}\right) \mathrm{Cl}_{2}\right]$ before and after $\mathrm{y}$-irradiation $\left(\mathrm{B}_{4}, \mathrm{~A}_{4}\right)$ complexes displayed signals at $2.16\left(\mathrm{~s}, \mathrm{H}, \mathrm{CH}_{3}\right)$, 3.77(s,2H,2 $\left.\mathrm{CH}_{2}\right), 5.56(\mathrm{~s}, \mathrm{H}, \mathrm{NH}), 6.51-7.52(\mathrm{~m}, 9 \mathrm{H}, \mathrm{Ar}-\mathrm{H}), 9.44(\mathrm{~s}, 1 \mathrm{H}, \mathrm{NH}), 9.61(\mathrm{~s}, 1 \mathrm{H}, \mathrm{NH})$ and 10.05(s, H, NH) as shown in Fig.3.

The effect of $y$-irradiation on the chemical shift of $\left[\mathrm{Zn}\left(\mathrm{H}_{2} \mathrm{~L}\right)_{2}\right] \mathrm{SO}_{4}$ and $\left[\mathrm{Cd}\left(\mathrm{H}_{2} \mathrm{~L}\right) \mathrm{Cl}\right] \mathrm{Cl}$ after $\mathrm{Y}$-irradiation are similar to before irradiation. 


\subsection{Mass spectroscopy}

Mass spectral data confirm the structure of the ligand as indicated by the molecular ion peak $\left(\mathrm{M}^{+}\right)$corresponding to their molecular weight. MS of $\mathrm{H}_{2} \mathrm{~L}_{\mathrm{B}}$ (Fig. 4) confirms the proposed formula, the observed peak at $\mathrm{m} / \mathrm{z}=$ $313 a m u(M)$ corresponding to the ligand moiety $\left(\mathrm{C}_{16} \mathrm{H}_{18} \mathrm{~N}_{4} \mathrm{OS}\right.$, atomic mass $\mathrm{m} / z=314$ molecular ion peak). The spectrum also shows important fragment ions in the range $m / z=51$ for $\left[\mathrm{C}_{4} \mathrm{H}_{4}-\mathrm{H}\right]^{+}, 77$ for $\left[\mathrm{C}_{6} \mathrm{H}_{5}\right]^{+}, 107$ for $\left[\mathrm{C}_{7} \mathrm{H}_{8} \mathrm{~N}\right]^{+}$base peak, 120 for $\left[\mathrm{C}_{7} \mathrm{H}_{6} \mathrm{NO}\right]^{+}, 135$ for $\left[\mathrm{C}_{8} \mathrm{H}_{7} \mathrm{~S}\right]^{+}, 280$ for $\left[\mathrm{C}_{14} \mathrm{H}_{13} \mathrm{~N}_{3} \mathrm{SO}-\mathrm{H}\right]^{+}$and 313 for $\left[\mathrm{C}_{16} \mathrm{H}_{18} \mathrm{~N}_{4} \mathrm{SO}-\right.$ $\mathrm{H}]^{+}$may be assigned to different fragments.

Also the spectrum of complex $\left(B_{3}\right)$ confirms the proposed formula by showing a molecular ion peak at $\mathrm{m} / \mathrm{z} 807.4$ amu corresponding to $\left[\mathrm{Zn}\left(\mathrm{H}_{2} \mathrm{~L}\right)_{2}\left(\mathrm{H}_{2} \mathrm{O}\right) \mathrm{SO}_{4}\right]\left(\mathrm{B}_{3}\right)$ (Fig.5) which coincide with its formula weight (calculated $\mathrm{m} / \mathrm{z}=$ $807.4 \mathrm{amu}$ ). The other fragments of the complex give the peak with various intensities at different $\mathrm{m} / \mathrm{z}$ values like at Calc/Found: $77\left[\mathrm{C}_{6} \mathrm{H}_{5}\right], 91\left[\mathrm{C}_{6} \mathrm{H}_{4} \mathrm{NH}\right], 120\left[\mathrm{C}_{9} \mathrm{H}_{8} \mathrm{NH}\right], 255\left[\mathrm{C}_{13} \mathrm{H}_{13} \mathrm{~N}_{5} \mathrm{O}\right], 535\left[\mathrm{C}_{24} \mathrm{H}_{24} \mathrm{~N}_{8} \mathrm{O}_{2}\right]$, $715\left[\mathrm{C}_{30} \mathrm{H}_{29} \mathrm{~N}_{8} \mathrm{O}_{4} \mathrm{~S}_{2}\right], 783\left[\mathrm{C}_{30} \mathrm{H}_{38} \mathrm{~N}_{8} \mathrm{O}_{7} \mathrm{~S}_{2} \mathrm{Zn}\right], 807.4 / 806\left[\mathrm{C}_{32} \mathrm{H}_{38} \mathrm{~N}_{8} \mathrm{O}_{7} \mathrm{~S}_{2} \mathrm{Zn}\right]$.

\section{4. FT-IR spectra}

\subsubsection{FT- IR spectra of the ligand before and after $y$-irradiation}

The comparison between the functional groups of the ligand before and after irradiation $\left(\mathrm{H}_{2} \mathrm{~L}_{B}\right.$ and $\left.\mathrm{H}_{2} \mathrm{~L}_{A}\right)$ the infrared spectra are presented in Fig. 6 and Table 2. It has been found that the functional groups of the ligand before $\gamma$-irradiation and after presented at 3384,3336 $\mathrm{cm}^{-1} ; 3263,3185 \mathrm{~cm}^{-1} ; 3150,3126 \mathrm{~cm}^{-1} ; 1672,1689 \mathrm{~cm}^{-1}$ and $749,750 \mathrm{~cm}^{-1}$ are attributed to the stretching frequencies of $\mathrm{u}(\mathrm{N} 4-\mathrm{H}), \mathrm{v}(\mathrm{N} 2-\mathrm{H})$ and $\mathrm{u}(\mathrm{N} 1-\mathrm{H}), \mathrm{v}(\mathrm{C}=\mathrm{O})$ and $\mathrm{u}(\mathrm{C}=\mathrm{S})$ respectively. After $\mathrm{Y}$-irradiation the bands corresponding to $\mathrm{U}(\mathrm{C}=0)$ shift to higher frequencies or slightly shift as compared with before $y$-irradiation [21]. After $Y$-irradiation the intensity of the peaks are more sharper than before $\mathrm{Y}$-irradiation. 


\begin{tabular}{|c|c|c|c|c|c|c|c|c|}
\hline No & Compound & $\begin{array}{l}\text { u (OH)/ } \\
\text { u (N4-H) }\end{array}$ & U (N2-H) & u (N1-H) & $\cup(C=0)$ & $\cup(\mathrm{C}=\mathrm{S})$ & u (M-0) & $\cup(M-N)$ \\
\hline & $\mathrm{H}_{2} \mathrm{~L}_{\mathrm{B}}$ & 3384 & 3263 & 3150 & 1672 & 749 & - & - \\
\hline & $\mathrm{H}_{2} \mathrm{~L}_{\mathrm{A}}$ & 3336 & 3185 & 3126 & 1689 & 750 & & \\
\hline \multirow[t]{2}{*}{$\mathrm{B}_{1}$} & $\mathrm{Cu}\left(\mathrm{H}_{2} \mathrm{~L}\right) \mathrm{I}$ & 3431 & 3293 & 3183 & 1597 & 749 & 603 & 529 \\
\hline & & & & 3150 & & & & \\
\hline \multirow[t]{2}{*}{$A_{1}$} & $\mathrm{Cu}\left(\mathrm{H}_{2} \mathrm{~L}\right) \mathrm{I}$ & 3434 & 3295 & 3185 & 1597 & 750 & 602 & 529 \\
\hline & & & & 3151 & & & & \\
\hline \multirow[t]{2}{*}{$\mathrm{B}_{2}$} & $\mathrm{Cu}\left(\mathrm{H}_{2} \mathrm{~L}\right)_{2}\left(\mathrm{ClO}_{4}\right)_{2}$ & 3437 & 3295 & 3153 & 1595 & 754 & 614 & 545 \\
\hline & & & 3206 & 3122 & & & & \\
\hline \multirow[t]{2}{*}{$\mathrm{A}_{2}$} & $\mathrm{Cu}\left(\mathrm{H}_{2} \mathrm{~L}\right)_{2}\left(\mathrm{ClO}_{4}\right)_{2}$ & 3433 & 3297 & 3154 & 1595 & 756 & 612 & 539 \\
\hline & & & 3209 & & & & & \\
\hline $\mathrm{B}_{3}$ & {$\left[\mathrm{Zn}\left(\mathrm{H}_{2} \mathrm{~L}\right)_{2}\left(\mathrm{H}_{2} \mathrm{O}\right)\right] \mathrm{SO}_{4}$} & 3420 & - & 3170 & 1593 & 754 & 614 & 512 \\
\hline \multirow[t]{2}{*}{$\mathrm{A}_{3}$} & {$\left[\mathrm{Zn}\left(\mathrm{H}_{2} \mathrm{~L}\right)_{2}\left(\mathrm{H}_{2} \mathrm{O}\right)\right] \mathrm{SO}_{4}$} & 3420 & - & 3138 & 1619 & 755 & 618 & 512 \\
\hline & & 3277 & & 3164 & 1593 & & & \\
\hline \multirow[t]{2}{*}{$\mathrm{B}_{4}$} & {$\left[\mathrm{Cd}\left(\mathrm{H}_{2} \mathrm{~L}\right) \mathrm{Cl}\right] \mathrm{Cl}$} & 3426 & 3268 & 3179 & 1685 & 744 & 591 & 533 \\
\hline & & & & & 1613 & & & \\
\hline \multirow[t]{2}{*}{$\mathrm{A}_{4}$} & {$\left[\mathrm{Cd}\left(\mathrm{H}_{2} \mathrm{~L}\right) \mathrm{Cl}\right] \mathrm{Cl}$} & 3433 & 3269 & 3179 & 1685 & 744 & 591 & 532 \\
\hline & & & & & 1617 & & & \\
\hline
\end{tabular}

Where: $\mathrm{B}=$ before $\mathrm{Y}$-irradiation, $\mathrm{A}=$ after $\mathrm{Y}$-irradiation

\subsubsection{FT-IR spectra of copper complexes before and after $y$-irradiation}

The FT-IR spectra of the $\mathrm{Cu}(\mathrm{I}, \mathrm{II})$ complexes before and after $\mathrm{Y}$-irradiation $\left(\mathrm{B}_{1}, \mathrm{~B}_{2}\right.$ and $\left.\mathrm{A}_{1}, \mathrm{~A}_{2}\right)$ show significant changes compared to the spectrum of the free ligand (Figs.7 and 8 ). The most important diagnostic spectral bands are summarized in Table 2. The IR spectra of copper complexes $\left(B_{1}, B_{2}\right.$ and $\left.A_{1}, A_{2}\right)$ show strong bands at $3431 ; 3437 ; 3293 ; 3295 ; 1597 ; 1595$ and $749 ; 754 \mathrm{~cm}^{-1}$ for before irradiation , also at $3434 ; 3433 ; 3295 ; 3297$; $1597 ; 1595$ and $750 ; 756 \mathrm{~cm}^{-1}$ for after irradiation which assigned to the stretching frequencies of $\mathrm{U}(\mathrm{N} 4-\mathrm{H}), \mathrm{U}(\mathrm{N} 2-$ $H), v(C=0)$ and $u(C=S)$. The bands corresponding to $u(N 4-H), v(N 2-H), v(C=0)$ and $u(C=S)$ appear at the same frequency or slightly shift to higher frequency after gamma irradiation. The IR spectra of $\mathrm{Cu}$ complexes before irradiation show that $\mathrm{v}(\mathrm{C}=\mathrm{O})$ and $\mathrm{v}(\mathrm{N} 2-\mathrm{H})$ shift to lower frequency upon complexation as compared of free ligand, indicating that coordination of the ligand in keto-form and the ligand behaves as neutral bidentate or tetradentate, coordination take place via $(\mathrm{C}=0)$ and $\mathrm{N}(2) \mathrm{H}$. 
The IR spectra of $\mathrm{Cu}(\mathrm{I}, \mathrm{II})$ complexes before and after $\mathrm{Y}$ - irradiation display new bands at 603, 614 and 529,545 $\mathrm{cm}^{-1}$ assigned to $\mathrm{U}(\mathrm{Cu}-\mathrm{O})$ and $\mathrm{U}(\mathrm{Cu}-\mathrm{N})$ respectively $[22,23]$. IR spectra of the complexes $\left(\mathrm{A}_{1}\right.$ and $\left.\mathrm{A} 2\right)$ showed that the intensity of the IR bands became more intense than before $y$-irradiation [24].

\subsubsection{IR spectra of Zinc(II) complexes before and after $Y$-irradiation}

The IR spectra of Zn(II) complexes (Fig.9) show strong bands at 3420,3170, $3164,1593,1619$ and 754,755 cm

1 before irradiation and after $\gamma$-irradiation which attributed to the stretching frequencies of $u(N 4-H) u(N 1-H)$, $\mathrm{u}(\mathrm{N} 2-\mathrm{H}), \mathrm{u}(\mathrm{C}=\mathrm{O})$ and $\mathrm{u}(\mathrm{C}=\mathrm{S})$ wagging vibrations, respectively. The IR spectra of $\mathrm{Zn}(\mathrm{II})$ complex before and after $\mathrm{Y}^{-}$ irradiation it is seen that the band corresponding to $\mathrm{v}(\mathrm{C}=0)$ was shifted to lower frequency upon complexation and the ligand behave as neutral tetradentate and coordination take place via two $(\mathrm{C}=\mathrm{O})$ and two $(\mathrm{N} 2-\mathrm{H})$, the band corresponding to $\mathrm{u}(\mathrm{N} 4-\mathrm{H})$ appears at the same frequency for before $\mathrm{Y}$ - irradiation and after $\mathrm{Y}$-irradiation , high intensity of the bands of function groups after $\gamma$-irradiation. The new bands appeared at 614,618 and 512 $\mathrm{cm}^{-1}$ are assigned to $\mathrm{u}(\mathrm{Zn}-\mathrm{O})$ and $\mathrm{u}(\mathrm{Zn}-\mathrm{N})$, respectively [25].

\subsubsection{FT-IR spectra of Cd(II) complexes before and after $\mathrm{Y}$-irradiation}

The FT-IR spectra of Cd(II) complexes (Fig.10) show strong bands at 3426, 3433; 3268, 3269; $3179 ; 1685$ and $744 \mathrm{~cm}^{-1}$ before irradiation and after $\mathrm{Y}$-irradiation which attributed to the stretching frequencies of $\mathrm{u}(\mathrm{N} 4-\mathrm{H}) \mathrm{U}(\mathrm{N} 2-$ $\mathrm{H}), \mathrm{v}(\mathrm{N} 1-\mathrm{H})$ and $\mathrm{u}(\mathrm{C}=\mathrm{S})$ wagging vibrations, respectively. The IR spectra of $\mathrm{Cd}(\mathrm{II})$ complexes before and after $\mathrm{Y}^{-}$ irradiation showed that the band corresponding to $\mathrm{U}(\mathrm{C}=0)$ is shifted to higher frequency upon complex formation and the ligand behave as neutral tridentate and coordination take place via $(C=0),(N 2-H)$ and $(C=S)$, the band corresponding to $\mathrm{u}(\mathrm{N} 4-\mathrm{H})$ shifts to higher frequency after $\mathrm{Y}$-irradiation, high intensity of the bands of function groups after $\gamma$-irradiation. The new bands appeared at 591and 533, $532 \mathrm{~cm}^{-1}$ assigned to u(Cd-O) and $\mathrm{u}(\mathrm{Cd}-\mathrm{N})$ respectively [26].

\subsection{UV- Vis spectra and magnetic moment properties}

The electronic spectral bands of the ligand $\left(\mathrm{H}_{2} \mathrm{~L}_{\mathrm{B}}\right)$ and $\mathrm{Cu}(\mathrm{I}, \mathrm{II}), \mathrm{Zn}(\mathrm{II})$ and $\mathrm{Cd}(\mathrm{II})$ complexes in DMF solution within the range $200-800 \mathrm{~nm}$ are tabulated in Table 3 and depicted in Figs.(11-14). The electronic spectrum of the ligand exhibits bands at 314, 292 and $279 \mathrm{~nm}$, respectively.

\subsubsection{The electronic absorption spectra of copper complexes before and after $\mathrm{Y}$-irradiation.}

The electronic spectra of $\mathrm{Cu}(\mathrm{I})$ complexes before and after irradiation ( $\mathrm{B}_{1}$ and $\left.\mathrm{A}_{1}\right)$ display bands at 300 and 409 $\mathrm{nm}$, respectively. $\mathrm{Cu}(\mathrm{I})$ ions have the $\mathrm{d}^{10}$ configuration and therefor the $\mathrm{Cu}(\mathrm{I})$ complexes should not exhibit any $\mathrm{d}$ $\mathrm{d}$ transition and have tetrahedral geometry [27].

While the electronic absorption spectra of $\mathrm{Cu}(\mathrm{II})\left(\mathrm{B}_{2}\right.$ and $\left.\mathrm{A}_{2}\right)$ before and after irradiation exhibited bands at 308, 398 and $653 \mathrm{~nm}$ in DMF refer to $\mathrm{L} \rightarrow \mathrm{M}$ charge transfer and $\mathrm{d} \rightarrow \mathrm{d}$ transitions, respectively in octahedral geometry [28] . Diamagnetic behavior of complex $\left(B_{1}\right)$ and the magnetic suitability value of complex (B2) is 1.78 B.M., which is an indicative of tetrahedral and octahedral geometry $[27,29]$.

\subsubsection{Zinc(II) complexes before and after y-irradiation}


The electronic absorption spectra of $\mathrm{Zn}$ (II) complexes before and after $\mathrm{y}$-irradiation displayed bands at 300, 282; 448 and $\mathrm{nm}$ in DMF solution, octahedral structure of $\mathrm{Zn}(\mathrm{II})$ complex is suggested which is diamagnetic in nature [30].

\subsubsection{Cadium(II) complexes before and after $\mathrm{Y}$-irradiation}

The electronic absorption spectra of $\mathrm{Cd}(\mathrm{II})$ complexes before and after $\mathrm{Y}$-irradiation displayed three bands at $284,390,610 \mathrm{~nm} ; 282,385$ and $608 \mathrm{~nm}$ in DMF solution attributed to charge transfer transition which assigned to tetrahedral geometry around $\mathrm{Cd}(\mathrm{II})$ ion $[31,32]$. The $\mathrm{Cd}(\mathrm{II})$ complexes are diamagnetic because of $\mathrm{d}^{10}$ electronic configuration of $\mathrm{Cd}(\mathrm{II})$ ion [33].

Table (3). The electronic absorption spectral data in DMF solution of ligand and its magnetic moment and metal complexes before and after irradiation value 


\begin{tabular}{|c|c|c|c|c|}
\hline \multirow[t]{2}{*}{ No } & \multirow[t]{2}{*}{ Compound } & \multicolumn{3}{|l|}{ Assignment } \\
\hline & & DMF & $\mu_{\text {eff }}$ (B.M.) & Geometry \\
\hline & $\mathrm{H}_{2} \mathrm{~L}_{\mathrm{B}}$ & $314,292,279$ & - & L \\
\hline \multirow[t]{2}{*}{$\mathrm{B}_{1}$} & $\mathrm{Cu}\left(\mathrm{H}_{2} \mathrm{~L}\right) \mathrm{I}$ & 300 & Dia & Tetrahedral \\
\hline & & 409 & & \\
\hline \multirow[t]{2}{*}{$A_{1}$} & $\mathrm{Cu}\left(\mathrm{H}_{2} \mathrm{~L}\right) \mathrm{I}$ & 300 & Dia & Tetrahedral \\
\hline & & 408 & & \\
\hline \multirow[t]{3}{*}{$B_{2}$} & $\mathrm{Cu}\left(\mathrm{H}_{2} \mathrm{~L}\right)_{2}\left(\mathrm{ClO}_{4}\right)_{2}$ & 653 & 1.74 & Octahedral \\
\hline & & 398 & & \\
\hline & & 308 & & \\
\hline \multirow[t]{3}{*}{$\mathrm{A}_{2}$} & $\mathrm{Cu}\left(\mathrm{H}_{2} \mathrm{~L}\right)_{2}\left(\mathrm{ClO}_{4}\right)_{2}$ & 653 & - & Octahedral \\
\hline & & 398 & & \\
\hline & & 308 & & \\
\hline \multirow[t]{2}{*}{$B_{3}$} & {$\left[\mathrm{Zn}\left(\mathrm{H}_{2} \mathrm{~L}\right)_{2}\left(\mathrm{H}_{2} \mathrm{O}\right)\right] \mathrm{SO}_{4}$} & 448 & Dia & Octahedral \\
\hline & & 300 & & \\
\hline \multirow[t]{2}{*}{$A_{3}$} & {$\left[\mathrm{Zn}\left(\mathrm{H}_{2} \mathrm{~L}\right)_{2}\left(\mathrm{H}_{2} \mathrm{O}\right)\right] \mathrm{SO}_{4}$} & 445 & Dia. & Octahedral \\
\hline & & 282 & & \\
\hline \multirow[t]{3}{*}{$\mathrm{B}_{4}$} & {$\left[\mathrm{Cd}\left(\mathrm{H}_{2} \mathrm{~L}\right) \mathrm{Cl}\right] \mathrm{Cl}$} & 610 & Dia. & Tetrahedral \\
\hline & & 390 & & \\
\hline & & 284 & & \\
\hline \multirow[t]{3}{*}{$\mathrm{A}_{4}$} & {$\left[\mathrm{Cd}\left(\mathrm{H}_{2} \mathrm{~L}\right) \mathrm{Cl}\right] \mathrm{Cl}$} & 608 & Dia. & Tetrahedral \\
\hline & & 385 & & \\
\hline & & 282 & & \\
\hline
\end{tabular}

\subsection{X-ray diffraction patterns}

XRD analysis was performed to confirm the crystal phase of compound. Samples $B_{1}-B_{3}$ and $A_{2}, A_{3}$ (was just before and after the irradiation as shown in Figs.15-17 and Table (4). The XRD patterns of the synthesized compounds were carried out in order to give an insight about the lattice dynamics of the compounds. The X-ray diffraction were recorded by using $\left(\mathrm{Cu}_{\mathrm{Ka}}\right)$ radiation $(1.5406 \AA)$. The intensity were collected over a $2 \mathrm{~h}$ range of $5-$ $90^{\circ}$. The average grain size of the samples was estimated using the diffraction intensity peak. The pattern found reflects a tracker on the fact that each solid describes a definite compound of a definite construction which is not contaminated with initial materials. This identification of the complexes was done by a known method [34].The mean grain size (D) of the particles was determined from the XRD line broadening measurement using the Scherrer equation: $\mathrm{D}=0.89 \lambda / \beta(\operatorname{Cos} \theta)$ 
An observable peak sharpness in the diffraction pattern indicates that the $\mathrm{Cu}(\mathrm{I}, \mathrm{II})$ and $\mathrm{Zn}(\mathrm{II})$ complexes before and after irradiation (Figs. 15-17 and Table (4) are in the nanometer range. The diameter of particles are found in nanorange scale as follows: $\mathrm{Cu}(\mathrm{I})$ complex before $\left(\mathrm{B}_{1}\right) 4.83 \mathrm{~nm} ; \mathrm{Cu}(\mathrm{II})$ complexes before and after irradiation $\left(\mathrm{B}_{2}\right.$ and $\left.A_{2}\right)$ 3.6, $5.79 \mathrm{~nm} ; \mathrm{Zn}(\mathrm{II})$ complexes before and after irradiation $\left(B_{3}\right.$ and $\left.A_{3}\right) 5.97,3.84 \mathrm{~nm}$. The nanoparticles sized complexes may serve strongly in different application fields in between the biological one [35].

Figs. (15-17) show that $\mathrm{Cu}(\mathrm{I}, \mathrm{II}), \mathrm{Zn}(\mathrm{II})$ complexes new peaks appear and some peaks displaced to longer interplanar spacings. The major factors tending to influence the intensity of powder patterns are structure factor, polarization factor, atomic scattering factor, multiplicities and preferred orientations. Upon irradiation, the position of atoms in the lattice changes and consequently, the scattering power also changes, leading to changes in intensity which display high resistance [36]. It should be noted that the $\mathrm{Zn}(\mathrm{II})$ complex $\left(\mathrm{A}_{3}\right)$ after irradiation increases the crystalline size than $B_{3}$ before irradiation .

Table 4. XRD data of $\mathrm{Cu}(\mathrm{I}, \mathrm{II}), \mathrm{Zn}(\mathrm{II})$ complexes before $\left(\mathrm{B}_{1}, \mathrm{~B}_{2}, \mathrm{~B}_{3}\right)$ and after irradiation $\left(\mathrm{A}_{2}, \mathrm{~A}_{3}\right)$ 


\begin{tabular}{|c|c|c|c|c|c|c|c|}
\hline \multicolumn{8}{|c|}{$B_{1}$} \\
\hline & & 8.2714 & 10.68097 & 0.36400 & 3.84 & & \\
\hline & & 21.1130 & 4.20458 & 0.42670 & 3.47 & & \\
\hline & & 23.6719 & 3.75554 & 0.34640 & 4.36 & & \\
\hline & & 25.3735 & 3.50741 & 0.31710 & 4.83 & & \\
\hline & & 42.0811 & 2.14551 & 0.28810 & 6.47 & & \\
\hline & & 49.08440 & 1.82802 & 0.31140 & 6.78 & & \\
\hline$A_{2}$ & & & & $\mathrm{~B}_{2}$ & & & \\
\hline 8.2002 & 10.77355 & 0.29380 & 4.75 & 5.4796 & 16.11496 & 0.32540 & 4.27 \\
\hline 23.6566 & 3.75794 & 0.40670 & 3.71 & 6.6475 & 13.28611 & 0.39730 & 3.51 \\
\hline 25.3683 & 3.50812 & 0.26470 & 5.79 & 8.7388 & 10.11071 & 0.38950 & 3.6 \\
\hline 28.2666 & 3.15466 & 0.29330 & 5.36 & 21.9376 & 4.04836 & 0.81600 & 1.83 \\
\hline 42.0890 & 2.14513 & 0.24600 & 7.59 & 23.5451 & 3.77548 & 0.52750 & 2.86 \\
\hline 49.8356 & 1.82831 & 0.21410 & 10.03 & 26.7430 & 3.33083 & 0.4900 & 3.16 \\
\hline$A_{3}$ & & & & $\mathrm{~B}_{3}$ & & & \\
\hline 6.6293 & 13.32254 & 0.36300 & 3.84 & 6.6762 & 13.22906 & 0.23340 & 5.97 \\
\hline 12.0777 & 7.32205 & 0.23540 & 6.02 & 11.1930 & 7.89872 & 0.24200 & 5.83 \\
\hline 13.4246 & 6.59030 & 0.26640 & 5.34 & 12.1177 & 7.29797 & 0.26890 & 5.27 \\
\hline 19.1065 & 4.64136 & 0.23490 & 6.24 & 13.4750 & 6.56576 & 0.24240 & 5.87 \\
\hline 20.0901 & 4.41629 & 0.26420 & 5.58 & 19.1602 & 4.62848 & 0.22050 & 6.65 \\
\hline 21.01650 & 4.19437 & 0.21000 & 7.07 & 20.1275 & 4.40817 & 0.26500 & 5.57 \\
\hline
\end{tabular}

\subsection{Thermal behavior of ligand and metal complexes before and after $\mathrm{y}$-irradiation}

The thermal behavior of the ligand and $\mathrm{Cu}(\mathrm{I}, \mathrm{II}), \mathrm{Zn}(\mathrm{II})$ and $\mathrm{Cd}(\mathrm{II})$ complexes before and after $\mathrm{y}$-irradiation was investigated by thermogravimetric technique in temperature range $25-800{ }^{\circ} \mathrm{C}$. The thermal behavior data of the ligand and $\mathrm{Cu}(\mathrm{I}, \mathrm{II}), \mathrm{Zn}(\mathrm{II})$ and $\mathrm{Cd}(\mathrm{II})$ complexes $\left(\mathrm{B}_{1}, \mathrm{~B}_{2}, \mathrm{~B}_{3}, \mathrm{~B}_{4}\right.$ and $\left.\mathrm{A}_{1}, \mathrm{~A}_{2}, \mathrm{~A}_{3}, \mathrm{~A}_{4}\right)$ before and after $\mathrm{y}$-irradiation are tabulated in Table 5 and depicted in Figs.(18-20).

\subsubsection{The ligand before and after $\gamma$-irradiation}

The TG curves of the ligand before and after $\gamma$-irradiation show that it is thermally stable till $140{ }^{\circ} \mathrm{C}, 125^{\circ} \mathrm{C}$, respectively. Also the TG curves show three decomposition steps in the temperature range $140-550{ }^{\circ} \mathrm{C} ; 125-510^{\circ} \mathrm{C}$ 
with total weight loss of Calc.100\% (Found 100\%) before and after $\gamma$-irradiation, respectively.

\subsubsection{Copper Complexes}

The TG thermograms of copper complexes $\left(B_{1}\right.$ and $\left.A_{1}\right)$ display three steps of decomposition as shown in Table 5 and Fig. (18). The first step of decomposition appeared within the temperature range 134- 255 and 147$293{ }^{\circ} \mathrm{C}$ with mass loss of $21 \%$ (calc. $21.2 \%$ ) and $28.7 \%$ (calc. $28.3 \%$ ) for complex $\left(B_{1}\right)$ and complex $\left(A_{1}\right)$, respectively, corresponding to loss of $\left(\mathrm{CH}_{3} \mathrm{C}_{6} \mathrm{H}_{5} \mathrm{NH}\right)$ and $(\mathrm{HI}+\mathrm{NH})$. The second step appeared at 258-410 and $294-385^{\circ} \mathrm{C}$ with mass loss of $19.0 \%$ (calc. $18.2 \%$ ) and $11.0 \%$ (calc. $10.1 \%$ ) for complexes $\left(B_{1}\right.$ and $\left.A_{1}\right)$, respectively, corresponding to further decompositions of organic ligand. The third TG decomposition step appeared within the temperature ranges $410-753^{\circ} \mathrm{C}$ and $385-701^{\circ} \mathrm{C}$ with mass loss of $36.0 \%$ (calc. $36.5 \%$ ) and $35.0 \%$ (calc.34.1\%), respectively, corresponding to complete decomposition of the organic ligand. The final remained product appeared above $735^{\circ} \mathrm{C}$ with remain mass of $24.0 \%$ (calc. $22.9 \%$ ) for complex $\left(B_{1}\right)$ and above $701{ }^{\circ} \mathrm{C}$ with mass remain of $25.3 \%$ (calc. $\left.25.3 \%\right)$ for complex $\left(\mathrm{A}_{1}\right)$ represent the formation of $(\mathrm{CuO}+3 \mathrm{C})$ and $(\mathrm{CuO}$ +4C) as a final product [37].

The TGA curve of copper complexes $\left(B_{2}\right.$ and $\left.A_{2}\right)$ display successive steps of decomposition as shown in Table 5 and Fig.(S1). The decomposition starts within the temperature range $420-620$ and $440-790{ }^{\circ} \mathrm{C}$ with mass loss of $82.0 \%$ (calc. 83\%) and 84.4\% (calc. 84.6\%) for complex $\left(B_{2}\right)$ and complex $\left(A_{2}\right)$, respectively. The final thermoproduct appeared at $620{ }^{\circ} \mathrm{C}$ with mass loss $18.0 \%$ (calc. $17 \%$ ) for complex $\left(\mathrm{B}_{2}\right)$ and at $790{ }^{\circ} \mathrm{C}$ with mass loss $15.6 \%$ (calc. $15.7 \%$ ) for complex $\left(\mathrm{A}_{2}\right)$ represents the formation of $(\mathrm{CuO}+7 \mathrm{C})$ and $(\mathrm{CuO}+6 \mathrm{C})$ as a final product [37].

\subsubsection{Zinc (II) Complex}

The TG thermograms of $\mathrm{Zn}(\mathrm{II})$ complexes $\left(\mathrm{B}_{3}, \mathrm{~A}_{3}\right)$ showed several steps of decomposition. The first step of decomposition appeared at $180-332$ and $170-354{ }^{\circ} \mathrm{C}$ with mass loss $39 \%$ (calc. $39.3 \%$ ) and $50 \%$ (calc. $50.3 \%$ ) for complexes $B_{3}$ and $A_{3}$ which corresponded to decomposition of organic ligand. The second step of decomposition appeared at 332-749 and 354-705 ${ }^{\circ} \mathrm{C}$ with mass loss 39\% (calc. 38.8\%) and 50\% (Calc.50 \%) ), respectively, for complexes $\left(B_{3}, A_{3}\right)$ which attributed to complete decomposition of organic ligand. The remaining weigh for complex $\left(\mathrm{B}_{3}\right)$ appeared above $704{ }^{\circ} \mathrm{C}$ and above $660{ }^{\circ} \mathrm{C}$ with mass remain of $22.1 \%$ (calc. $21 \%$ ) and $21 \%$ (calc. $21.7 \%$ )corresponding to the formation of $\mathrm{ZnO}$ as final products in addition to $7 \mathrm{C}$ residue [37].

\subsubsection{Cadmium (II) Complexes}

The TG thermograms of $\mathrm{Cd}(\mathrm{II})$ complexes $\left(\mathrm{B}_{4}, \mathrm{~A}_{4}\right)$ display successive decomposition steps within the temperature range $134-789$ and $139-718^{\circ} \mathrm{C}$ with mass loss $88.2 \%$ (calc. $88.5 \%$ ), respectively for complexes $\left(\mathrm{B}_{4}\right.$, $\mathrm{A}_{4}$ ), are assigned to the material decomposition. The final weight residue appeared at above 789 and $718{ }^{\circ} \mathrm{C}$ corresponded to $\mathrm{Cd}$ and $\mathrm{CdO}$ for complexes $\left(\mathrm{B}_{4}, \mathrm{~A}_{4}\right)$ as thermo finial products in addition to carbon residue for complex $\left(\mathrm{A}_{4}\right)$ [38].

Table 5. Thermal analysis data of ligand and $\mathrm{Cu}(\mathrm{I}, \mathrm{II}), \mathrm{Zn}(\mathrm{II})$ and $\mathrm{Cd}(\mathrm{II})$ complexes before and after irradiaton 


\begin{tabular}{|c|c|c|c|c|c|c|}
\hline \multirow[t]{2}{*}{ No. } & \multirow{2}{*}{$\begin{array}{l}\text { Molecular } \\
\text { formulae }\end{array}$} & \multirow{2}{*}{$\begin{array}{l}\text { Temp. } \\
\text { range }\left({ }^{\circ} \mathrm{C}\right) \\
\text { DTG }\end{array}$} & \multirow{2}{*}{$\begin{array}{l}\text { Temp. } \\
\text { range }\left({ }^{\circ} \mathrm{C}\right) \\
\text { TGA }\end{array}$} & \multicolumn{2}{|c|}{ Mass loss \% } & \multirow[t]{2}{*}{ Assignment } \\
\hline & & & & Found & Calc. & \\
\hline & \multirow[t]{2}{*}{$\mathrm{H}_{2} \mathrm{~L}_{\mathrm{B}}$} & \multirow[t]{2}{*}{180,500} & 140 & - & - & \multirow[t]{2}{*}{ Melting Decomposition } \\
\hline & & & $140-550$ & 100 & 100 & \\
\hline & \multirow[t]{2}{*}{$\mathrm{H}_{2} \mathrm{~L}_{\mathrm{A}}$} & \multirow[t]{2}{*}{180,550} & 125 & - & - & \multirow[t]{2}{*}{ Melting Decomposition } \\
\hline & & & $125-510$ & 100 & 100 & \\
\hline \multirow[t]{4}{*}{$\mathrm{B}_{1}$} & \multirow[t]{4}{*}{$\mathrm{Cu}\left(\mathrm{H}_{2} \mathrm{~L}\right) \mathrm{I}$} & 206 & $134-255$ & 21 & 21.2 & Loss of $\mathrm{CH}_{3} \mathrm{C}_{6} \mathrm{H}_{5} \mathrm{NH}$ \\
\hline & & 313 & $255-410$ & 19.0 & 18.2 & Further Decomposition \\
\hline & & \multirow[t]{2}{*}{639} & \multirow[t]{2}{*}{$410-753$} & 36.0 & 36.5 & $\begin{array}{l}\text { Completion of decomposition } \\
\text { of organic ligand }\end{array}$ \\
\hline & & & & 24 & 22.9 & $\mathrm{CuO}+3 \mathrm{C}$ \\
\hline \multirow[t]{5}{*}{$A_{1}$} & \multirow[t]{5}{*}{$\mathrm{Cu}\left(\mathrm{H}_{2} \mathrm{~L}\right) \mathrm{I}$} & 287 & $147-293$ & 28.7 & 28.3 & Loss of $\mathrm{CH}_{3} \mathrm{C}_{6} \mathrm{H}_{5} \mathrm{NH}+\mathrm{HI}+\mathrm{NH}$ \\
\hline & & 314 & 294-385 & 11 & 10.1 & Further Decomposition \\
\hline & & \multirow[t]{3}{*}{602} & \multirow[t]{3}{*}{$385-701$} & 35 & 34.1 & Complete Decomposition \\
\hline & & & & & & of organic ligand \\
\hline & & & & 25.3 & 25.3 & $\mathrm{CuO}+4 \mathrm{C}$ \\
\hline \multirow[t]{2}{*}{$\mathrm{B}_{2}$} & \multirow[t]{2}{*}{$\mathrm{Cu}\left(\mathrm{H}_{2} \mathrm{~L}\right)_{2}\left(\mathrm{ClO}_{4}\right)_{2}$} & & $420-620$ & 82 & 83 & Decomposition \\
\hline & & $\begin{array}{l}547,637 \\
685\end{array}$ & at 620 & 18 & 17 & $\mathrm{CuO}+7 \mathrm{C}$ as final product \\
\hline \multirow[t]{2}{*}{$A_{2}$} & \multirow[t]{2}{*}{$\mathrm{Cu}\left(\mathrm{H}_{2} \mathrm{~L}\right)_{2}\left(\mathrm{ClO}_{4}\right)_{2}$} & \multirow[t]{2}{*}{429} & $440-790$ & 84.4 & 84.3 & Decomposition \\
\hline & & & at 790 & 15.6 & 15.7 & $\mathrm{CuO}+6 \mathrm{C}$ as final product \\
\hline \multirow[t]{3}{*}{$\mathrm{B}_{3}$} & \multirow[t]{3}{*}{$\mathrm{Zn}\left(\mathrm{H}_{2} \mathrm{~L}\right)_{2}\left(\mathrm{H}_{2} \mathrm{O}\right) \mathrm{SO}_{4}$} & 216 & $180-332$ & 39 & 39.3 & decomposition \\
\hline & & 384 & $332-499$ & 39 & 38.8 & \multirow{2}{*}{$\begin{array}{l}\text { Complete decomposition of the } \\
\text { organic ligand } \\
\mathrm{ZnO}_{2}+7 \mathrm{C}\end{array}$} \\
\hline & & 646 & 499-704 & 22 & 21 & \\
\hline \multirow[t]{3}{*}{$A_{3}$} & \multirow[t]{3}{*}{$\mathrm{Zn}\left(\mathrm{H}_{2} \mathrm{~L}\right)_{2}\left(\mathrm{H}_{2} \mathrm{O}\right) \mathrm{SO}_{4}$} & 220 & $170-374$ & 50 & 50.3 & Decomposition \\
\hline & & \multirow[t]{2}{*}{599} & $374-660$ & 29 & 28 & \multirow{2}{*}{$\begin{array}{l}\text { Complete decomposition of the } \\
\text { organic ligand } \\
\mathrm{ZnO}_{2}+7 \mathrm{C}\end{array}$} \\
\hline & & & At 660 & 21 & 21.7 & \\
\hline $\mathrm{B}_{4}$ & $\mathrm{Cd}\left(\mathrm{H}_{2} \mathrm{~L}\right) \mathrm{Cl}_{2}$ & 186 & & 88.2 & 88.4 & decomposition \\
\hline & & 257 & $134-789$ & 11.8 & 11.6 & $\begin{array}{l}\text { Complete decomposition of the } \\
\text { organic ligand }\end{array}$ \\
\hline
\end{tabular}




\begin{tabular}{|llllll|} 
& \multicolumn{1}{c}{335} & At 789 & & & Cd \\
\hline & 701 & & & & \\
\hline $\mathbf{A}_{4} \quad \mathrm{Cd}\left(\mathrm{H}_{2} \mathrm{~L}\right) \mathrm{Cl}_{2}$ & 186 & $139-718$ & 82.7 & 82.3 & decomposition \\
& 331 & at 718 & 17.3 & 46.6 & Complete decomposition \\
& 644 & & & 17.7 & proccess \\
& & & & & CdO $+2 \mathrm{C}$ \\
\hline
\end{tabular}

From all of the above, the suggested chemical structure of metal complexes are shown in Scheme 1

\subsection{Structure characterization with DFT study}

The geometric structures of $\mathrm{H}_{2} \mathrm{~L}_{\mathrm{B}}$ ligand and its metal complexes were optimized as shown in (Fig. 21). Upon coordination of $\mathrm{H}_{2} \mathrm{~L}_{B}$ to the metal atom, some bond lengths become slightly longer than in the free ligand accompanied with changes in angles that were clarified in Table 6 as (C5-08), (N4-C5), (N7-C6) and (N3-C2). This finding is due to the formation of M-N \& M-O bonds in all complexes that make the C-O (S. S. Hassan, 2017, S. S. Hassan, 2018) and C-N bonds weaker (Safaa S. Hassan, 2020). It was observed from the energy values that the stability of ligand increases upon complexation with $\mathrm{Zn}$ (II) and $\mathrm{Cu}(\mathrm{II})$ ions in ratio (1 to 2 ) metal to ligand. The ionic complexes $(\mathrm{Cd}(\mathrm{II}) \&$ and $\mathrm{Cu}(\mathrm{I}))$ show higher energy values than the parent ligand. The polarity of ligand increased after complexation by its coordination to metal ions as it is evident from the magnitude of their dipole moments. The ionic complexes have higher polarity than the non-electrolytic complexes. The molecular properties are mentioned in Table 6 which can be calculated as follows: Hardness $\eta=(I-A) / 2$, Softness $(S) S=1 /$ $2 \eta$, Chemical potential $(\mu), \mu=-(I+A) / 2$ and Electronegativity $(X), X=(I+A) / 2 \eta$. From HOMO-LUMO gap (DE), one can detect whether the molecule is hard or soft. Larger DE corresponding to harder molecule and small one related to the softer molecule. The polarizability of the soft molecule is more than the hard one because it needs lower energy to excitation, thus softness $(S)$ and hardness $(\eta)$ are properties of molecule that measures the chemical reactivity. We found the ligand and $\mathrm{Cu}(\mathrm{I})$ complex were more harder than the remaining complexes. The generated molecular orbital energy diagrams HOMO and LUMO are presented in (Figure 22).

The formal charge of cadmium, zinc and copper were $\mathrm{Cd}^{2+}, \mathrm{Zn}^{2+}, \mathrm{Cu}^{2+}, \mathrm{Cu}^{+}$but the calculated charges on [Cd $\left.\left(\mathrm{H}_{2} \mathrm{~L}\right) \mathrm{Cl}\right] \mathrm{Cl}, \mathrm{Cu}\left(\mathrm{H}_{2} \mathrm{~L}\right)_{2}\left(\mathrm{ClO}_{4}\right)_{2}, \mathrm{Cu}\left(\mathrm{H}_{2} \mathrm{~L}\right) \mathrm{I}$ and $\mathrm{Zn}\left(\mathrm{H}_{2} \mathrm{~L}\right)_{2}\left(\mathrm{H}_{2} \mathrm{O}\right) \mathrm{SO}_{4}$ were $0.856,0.579,0.413$ and 0.884 , respectively. It can be explained due to the charge transfer from the examined ligand to the central metal ions i.e. $L \rightarrow M$. So, the theoretical calculations confirm the results that obtained from the analysis tools which were discussed in the previous characterization part.

Table 6. Ground state properties of $\mathrm{H}_{2} \mathrm{~L}$ ligand using B3LYP/6-31G(++)d,p and its metal complexes using B3LYP/LANL2DZ 


\begin{tabular}{|c|c|c|c|c|c|}
\hline Parameter & $\mathrm{H}_{2} \mathrm{~L}_{\mathrm{B}}$ & {$\left[\mathrm{Cu}\left(\mathrm{H}_{2} \mathrm{~L}\right) \mathrm{l}\right]$} & {$\left[\mathrm{Cu}\left(\mathrm{H}_{2} \mathrm{~L}\right)_{2}\left(\mathrm{ClO}_{4}\right)_{2}\right]$} & {$\left[\left[\mathrm{Zn}\left(\mathrm{H}_{2} \mathrm{~L}\right)_{2}\left(\mathrm{H}_{2} \mathrm{O}\right)\right] \mathrm{SO}_{4}\right.$} & {$\left[\mathrm{Cd}\left(\mathrm{H}_{2} \mathrm{~L}\right) \mathrm{Cl}\right] \mathrm{Cl}$} \\
\hline $\mathrm{E}_{\mathrm{T}}$, Hartree & -1312.9304 & -1135.3041 & -2676.2810 & -1991.3548 & -986.9751 \\
\hline $\mathrm{E}_{\text {Hомо, }} \mathrm{eV}$ & -5.22 & -6.06 & -6.04 & -2.52 & -9.06 \\
\hline$E_{\text {LUMO, }} \mathrm{eV}$ & -1.38 & -3.88 & -4.91 & -1.72 & -8.46 \\
\hline $\mathrm{DE}, \mathrm{eV}$ & 3.84 & 2.18 & 1.13 & 0.80 & 0.6 \\
\hline $\mathrm{I}=-\mathrm{E}_{\text {номо }}, \mathrm{eV}$ & 5.22 & 6.06 & 6.04 & 2.52 & 9.06 \\
\hline$A=-E_{\text {LUMO }}, e V$ & 1.38 & 3.88 & 4.91 & 1.72 & 8.46 \\
\hline $\mathrm{c}, \mathrm{eV}$ & 3.30 & 4.97 & 5.47 & 2.12 & 8.76 \\
\hline$h, e V$ & 1.92 & 1.09 & 0.565 & 0.4 & 0.30 \\
\hline $\mathrm{S}, \mathrm{eV}^{-1}$ & 0.26 & 0.45 & 0.88 & 1.25 & 1.67 \\
\hline$\mu, \mathrm{eV}$ & -3.30 & -4.97 & -5.47 & -2.12 & -8.76 \\
\hline Dipole Moment & 3.2200 & 15.1634 & 3.2461 & 8.2389 & 15.7912 \\
\hline
\end{tabular}

${ }^{a} \mathrm{E}$ : the total energy (a.u.), ${ }^{b} \mathrm{HOMO}$ : highest occupied molecular orbital (eV) and ${ }^{c}$ LUMO: lowest unoccupied molecular orbital (eV), $\mathrm{DE}=\mathrm{E}_{\text {lumo }}-\mathrm{E}_{\mathrm{Homo}}$

Table 7. Some of the optimized bond lengths, $\AA$ and bond angles, degrees, for $\left(\mathrm{H}_{2} \mathrm{~L}\right)$ and complexes using B3LYP/6-311G(++)d,p. 


\begin{tabular}{|c|c|c|c|c|c|}
\hline Bond length $\left(A^{\circ}\right)$ & $\mathrm{H}_{2} \mathrm{LB}$ & {$\left[\mathrm{Cu}\left(\mathrm{H}_{2} \mathrm{~L}\right) 1\right]$} & {$\left[\mathrm{Cu}\left(\mathrm{H}_{2} \mathrm{~L}\right)_{2}\left(\mathrm{ClO}_{4}\right)_{2}\right]$} & {$\left[\mathrm{Zn}\left(\mathrm{H}_{2} \mathrm{~L}\right)_{2}\left(\mathrm{H}_{2} \mathrm{O}\right)\right] \mathrm{SO}_{4}$} & {$\left[\mathrm{Cd}\left(\mathrm{H}_{2} \mathrm{~L}\right) \mathrm{Cl}\right] \mathrm{C}$} \\
\hline $\mathrm{R}(\mathrm{M}-\mathrm{Cl})$ & - & 2.19937 & -- & - & 2.37881 \\
\hline $\mathrm{R}(\mathrm{M}-08)$ & - & 2.22007 & 1.93603 & 2.06440 & 2.36369 \\
\hline R(M-N3) & - & 1.96135 & 2.65910 & 2.04013 & 1.94974 \\
\hline $\mathrm{R}\left(\mathrm{M}-\mathrm{O}-\mathrm{ClO}_{3}\right)$ & - & -- & 1.97195 & - & 3.04748 \\
\hline $\mathrm{R}(\mathrm{M}-\mathrm{S} 1)$ & - & 2.60876 & - & 2.37828 & - \\
\hline $\mathrm{R}\left(\mathrm{M}-\mathrm{O}-\mathrm{H}_{2}\right)$ & - & - & - & 2.10239 & - \\
\hline $\mathrm{R}(\mathrm{C} 2-\mathrm{S} 1)$ & 1.73273 & 1.80438 & - & 1.80719 & 1.46624 \\
\hline $\mathrm{R}(\mathrm{C} 5-\mathrm{O} 8)$ & 1.25861 & 1.27510 & 1.27514 & 1.30843 & 1.45986 \\
\hline $\mathrm{R}(\mathrm{N} 4-\mathrm{C} 5)$ & 1.35538 & 1.36229 & 1.34735 & 1.39788 & 1.32019 \\
\hline $\mathrm{R}(\mathrm{N} 3-\mathrm{C} 2)$ & 1.36138 & 1.32646 & 1.46312 & 1.47620 & 1.35331 \\
\hline $\mathrm{R}(\mathrm{N} 7-\mathrm{C6})$ & 1.44027 & 1.45935 & 1.45631 & 1.47188 & 1.45929 \\
\hline R(N9-C2) & 1.37062 & 1.37303 & 1.34881 & 1.42723 & 1.36423 \\
\hline A(N3-M-Cl1) & - & 175.483 & - & - & 68.909 \\
\hline $\mathrm{A}(\mathrm{Cl} 1-\mathrm{M}-\mathrm{Cl} 2)$ & - & - & - & - & - \\
\hline $\mathrm{A}(\mathrm{Cl} 1-\mathrm{M}-08)$ & - & 108.139 & - & - & 118.508 \\
\hline A(O8-M-N3) & - & 76.143 & 71.994 & 80.528 & 68.909 \\
\hline A(M-N3-N4) & - & 118.525 & 98.360 & 103.377 & 118.280 \\
\hline$A(M-08-C 2)$ & - & 110.583 & 125.403 & 111.998 & 116.580 \\
\hline A(N3-M-O-ClO3) & - & - & 98.448 & - & - \\
\hline $\mathrm{A}\left(\mathrm{O} 8 \mathrm{-M}-\mathrm{O}-\mathrm{H}_{2}\right)$ & - & - & -- & 90.905 & - \\
\hline A(N3-M-S1) & - & 66.774 & - & 81.522 & - \\
\hline
\end{tabular}

\subsection{Antibacterial Activity}

The synthesized ligand and its metal complexes were separately exposed to gamma irradiation to test their improvement as active antibacterial drugs [39]. Results in Table (8), Figs. 23 and 24 showed antibacterial activity against the tested microbes. Generally, it was found that antibacterial activity of both the synthetic ligand and metal complexes before and after $y$-irradiation was proportionally increased with increased concentration. The tested compounds before and after $\gamma$-irradiation are found to have remarkable biological activity. The results in Table (8) Figs. (23 and 24) indicate that in case of E.coli for $1 \mu \mathrm{g} / \mathrm{ml}$ and $5 \mu \mathrm{g} \backslash \mathrm{ml}$ the corresponding $\mathrm{Cu}(\mathrm{II})$ and $\mathrm{Zn}$ (II) complexes showed much better antibacterial activity with respect to the individual ligand and complexes against the same microorganism under identical experimental conditions, the antibacterial activity of the tested compounds were found to follow the order: $A_{2}>A_{3}>B_{1}>A_{1}>B_{3}>B_{2}>A_{4}>H_{2} L_{A}>H_{2} L_{B}>B_{4}$ for $1 \mu \mathrm{g} \backslash \mathrm{ml}$ before 
and after irradiation, Antibacterial activity of $5 \mu \mathrm{g} / \mathrm{ml}$ concentration in case of E.coli follow the order $A_{3}>B_{1}>A_{2}>$ $B_{3}>A_{1}>H_{2} L_{A}>H_{2} L_{B}>A_{4}>B_{4}$ before and after irradiation. On the other hand, antibacterial activity was recorded when using the ligand and metal complexes with S.pyogenes follow the order: $A_{3}>A_{2}>A_{1}>B_{3}>A_{4}>H_{2} L_{A}$ $>\mathrm{H}_{2} \mathrm{~L}_{\mathrm{B}}>\mathrm{B}_{4}>\mathrm{B}_{2}>\mathrm{B}_{1}$ for before and after irradiation with $1 \mu \mathrm{g} / \mathrm{ml}$ concentration [23]. Antibacterial activity of $5 \mu \mathrm{g} / \mathrm{ml}$ concentration for both the free acyclic ligand and its complexes before and after irradiation followed the order: $\mathrm{B}_{2}=\mathrm{B}_{3}>\mathrm{H}_{2} \mathrm{~L}_{\mathrm{A}}>\mathrm{A}_{2}>\mathrm{A}_{1}>\mathrm{A}_{3}>\mathrm{H}_{2} \mathrm{~L}_{\mathrm{B}}>\mathrm{B}_{1}$ when compounds were used with $S$. pyogenes [40]. Results suggested that in case of $1 \mu \mathrm{g} / \mathrm{ml}$ and $5 \mu \mathrm{g} / \mathrm{ml} \mathrm{Cu}(\mathrm{II})$ and $\mathrm{Zn}(\mathrm{II})$ complexes have higher activity than other complexes The chelation could facilitate the ability to cross the cell membrane of $E$. coli and can be explained by Tweedy's chelation theory. Chelation/complexation could enhance the lipophilic nature of the central metal atom which in turn, favors its permeation through the lipoid layer of the membrane thus causing the metal complex to cross the bacterial membrane more effectively thus increasing the activity of the complexes. Besides from this many other factors such as solubility, dipole moment, conductivity influenced by metal ion may be possible reasons for remarkable antibacterial activities of these complexes [41]. Exposure to gamma irradiation remarkably enhanced the antibacterial activity for both the ligand and its complexes when it was used in case of E.coli. The activity also increased after irradiation in case of $S$. pyogenes. This may be attributed to the different nature of the cell wall for both microbes which may be correlated with other factors such as solubility, dipole moment, and conductivity influenced by metal ion. Additionally, exposure to gamma irradiation increased the antibacterial activity of both the free a cyclic ligand and their complexes when used with both concentrations $(1 \mu \mathrm{g} / \mathrm{ml}$ and $5 \mu \mathrm{g} / \mathrm{ml}$ ) in case of the Gram positive $S$. pyogenes bacterium. It also has been observed that some moieties such as $\mathrm{N}(2) \mathrm{H}$ linkage introduced into such compounds exhibits extensive biological that may be responsible for increase in hydrophobic character and liposolubility of the molecules in crossing the cell membrane of the microorganism and enhance biological utilization ratio and activity of complexes activity [42]. The antibacterial studies of the prepared compounds screened against both Gram positive and Gram negative bacteria proved that these compounds exhibit remarkable antibacterial activity and can be used in the future as therapeutic drugs for pathogenic bacterial diseases.

Table 8 . Antibacterial activity of ligand and their metal complexes 


\begin{tabular}{|c|c|c|c|c|c|}
\hline \multirow[t]{3}{*}{ No. } & \multirow[t]{3}{*}{ Compound } & \multicolumn{4}{|c|}{ Inhibition \% } \\
\hline & & \multicolumn{2}{|c|}{ S. pyogenes } & \multicolumn{2}{|l|}{ E.coli } \\
\hline & & $1 \mu \mathrm{g} / \mathrm{ml}$ & $5 \mu \mathrm{g} / \mathrm{ml}$ & $1 \mu \mathrm{g} / \mathrm{ml}$ & $5 \mu \mathrm{g} / \mathrm{ml}$ \\
\hline & $\mathrm{H}_{2} \mathrm{~L}_{B}$ & 75.32 & 91.24 & 48.76 & 56.23 \\
\hline & $\mathrm{H}_{2} \mathrm{~L}_{\mathrm{A}}$ & 74.40 & 95.32 & 52.11 & 66.76 \\
\hline$B_{1}$ & $\mathrm{Cu}\left(\mathrm{H}_{2} \mathrm{~L}\right) \mathrm{I}$ & 57.66 & 88.3 & 86.44 & 92.13 \\
\hline$A_{1}$ & $\mathrm{Cu}\left(\mathrm{H}_{2} \mathrm{~L}\right) \mathrm{I}$ & 88.41 & 94.31 & 82.8 & 86.50 \\
\hline $\mathrm{B}_{2}$ & $\mathrm{Cu}\left(\mathrm{H}_{2} \mathrm{~L}\right)_{2}\left(\mathrm{ClO}_{4}\right)_{2}$ & 64.5 & 96.16 & 70.55 & 54.92 \\
\hline$A_{2}$ & $\mathrm{Cu}\left(\mathrm{H}_{2} \mathrm{~L}\right)_{2}\left(\mathrm{ClO}_{4}\right)_{2}$ & 90.34 & 94.82 & 97.63 & 89.34 \\
\hline $\mathrm{B}_{3}$ & {$\left[\mathrm{Zn}\left(\mathrm{H}_{2} \mathrm{~L}\right)_{2}\left(\mathrm{H}_{2} \mathrm{O}\right)\right] \mathrm{SO}_{4}$} & 8.16 & 96.16 & 82.16 & 87.3 \\
\hline$A_{3}$ & {$\left[\mathrm{Zn}\left(\mathrm{H}_{2} \mathrm{~L}\right)_{2}\left(\mathrm{H}_{2} \mathrm{O}\right)\right] \mathrm{SO}_{4}$} & 91.42 & 93.23 & 92.6 & 96.83 \\
\hline $\mathrm{B}_{4}$ & {$\left[\mathrm{Cd}\left(\mathrm{H}_{2} \mathrm{~L}\right) \mathrm{Cl}\right] \mathrm{Cl}$} & 48.23 & 58.31 & 43.66 & 32.8 \\
\hline $\mathrm{A}_{4}$ & {$\left[\mathrm{Cd}\left(\mathrm{H}_{2} \mathrm{~L}\right) \mathrm{Cl}\right] \mathrm{Cl}$} & 74.42 & 65.03 & 56.63 & 46.43 \\
\hline
\end{tabular}

\section{The molecular docking}

To understand the interaction of all the synthesized molecules with topoisomerase II DNA gyrase enzymes, the crystal structure of topoisomerase II was downloaded from Protein Data Bank (PDB ID: 2XCT) and the molecular docking studies were performed using the Moe program. The protein ligand interaction plays a significant role in structural based drug designing. The different types of interactions are mentioned in Table 9 and seen in Fig. 25. The preferred compounds $\mathrm{Cd}(\mathrm{II}) \mathrm{Cu}(\mathrm{II})$ and $\mathrm{Zn}$ (II) complexes had a scoring value of $-5.02,-9.41$ and -10.87 ,respectively. The $\mathrm{Zn}$ (II) complex showed the highest binding affinity and interaction with topoisomerase II DNA gyrase enzymes (2XCT) by using most types of protein binding interactions. The binding affinity of our compounds achieved higher or the same values numerous previous works against the same type of protein $[43,44]$. The molecular docking of our work supported that the chelates are more active than their parent ligand against the same microorganism as mentioned also in many of our previous works [45-48].

Table 9: Comparison of binding affinity of complexes against topoisomerase II DNA gyrase enzymes (PDB Code: 2XCT) 


\begin{tabular}{|lll|}
\hline Antitumor docking 4 jsv & \\
\hline Compound & $\begin{array}{l}\text { Involved amino acids(scoring } \\
\text { energy) }\end{array}$ & Type of interaction \\
\hline $\mathrm{H}_{2} \mathrm{~L}_{\mathrm{B}}$ & Lys-1270(-2.99) & Side chain donor \\
\hline $\left.\mathrm{Cu}\left(\mathrm{H}_{2} \mathrm{~L}\right) !\right]$ & Asp-1114(-3.30) & Side chain acceptor \\
\hline$\left[\mathrm{Cu}\left(\mathrm{H}_{2} \mathrm{~L}\right)_{2}\left(\mathrm{ClO}_{4}\right)_{2}\right]$ & Arg-1299 (-9.41) & Arene-cation interaction \\
{$\left[\mathrm{Zn}\left(\mathrm{H}_{2} \mathrm{~L}\right)_{2}\right] \mathrm{SO}_{4}$} & $\begin{array}{l}\text { Glu-585, Pro-1080, Tyr-1150 and } \\
\text { His-1081(-10.87) }\end{array}$ & $\begin{array}{l}\text { Side chain acceptor, Backbone acceptor, Arene- } \\
\text { arene and Arene-cation }\end{array}$ \\
\hline $\left.\mathrm{Cd}\left(\mathrm{H}_{2} \mathrm{~L}\right) \mathrm{Cl}\right] \mathrm{Cl}$ & Ser1584(-5.02) & Solvent contact \\
\hline
\end{tabular}

\section{Conclusions}

In this work new $\mathrm{Cu}(\mathrm{I}, \mathrm{II}), \mathrm{Zn}(\mathrm{II})$ and $\mathrm{Cd}(\mathrm{II})$ complexes of thiosemicarbazide ligand (1-(p-(methylanilinocetyl-4phenyl-thiosemicarbazide) $\left(H_{2} L_{B}\right)$ have been prepared and characterized by ${ }^{1} H N M R$, Mass spectra, IR, elemental analyses, molar conductance, UV-visible spectra, magnetic susceptibility measurements, thermogravimetric analysis (TGA/DTG) and X-ray diffraction pattern before and after $\gamma$-irradiation. The biological activity of unirradiated and irradiated compounds were investigated. The results obtained can be summarized as follows:

1. The ligand behaves as neutral tridentate , tetradentate or monobasic tetradentate, coordinated to the ligand through the $(\mathrm{C}=0), \mathrm{N}(2) \mathrm{H},(\mathrm{C}=\mathrm{S})$ and coordination take place via enolic oxygen or $(\mathrm{C}=0)$ and two $\mathrm{N}(2) \mathrm{H}$ for complexes $\left(\mathrm{B}_{2}\right.$ and $\left.\mathrm{B}_{3}\right)$.

2. 1 H NMR spectra of ligand after irradiation shows higher the intensity of the bands than before irradiation.

3. IR exhibits sharper of the bands and the increase in the stability of the compounds by using radiation

4. X-ray diffraction patterns improve the crystallite size of the complexes by using gamma-irradiation.

5. The proposed structures of complexes were geometrically optimized, also showed that the $\mathrm{Cu}(\mathrm{I}, \mathrm{II}), \mathrm{Zn}(\mathrm{II})$ and $\mathrm{Cd}(\mathrm{II})$ complexes have four and six coordination geometries; this is also in a good agreement with the experimental results.

6. In vitro antibacterial activity of all synthesized compounds indicated that they are potent antibacterial agents. Besides, This indicate that an increase in the antibacterial activity increases.

7. The molecular docking study supported the antibacterial results.

\section{Declarations}

Sample Availability: Samples of the compounds are available from the authors. 


\section{References}

1. Tahmeena, K., Rumana, A., Seema, J., \& Khan, A. R. (2015). Anticancer potential of metal thiosemicarbazone complexes: a review. Der Chemica Sinica, 6, 1-11.

2. Tada, R., Chavda, N., \& Shah, M. K. (2011). Synthesis and characterization of some new thiosemicarbazide derivatives and their transition metal complexes. Journal of Chemical and Pharmaceutical Research, 3(2), 290-297.

3. Scovill, J. P., Klayman, D. L., \& Franchino, C. F. (1982). 2-Acetylpyridine thiosemicarbazones. 4. Complexes with transition metals as antimalarial and antileukemic agents. Journal of Medicinal Chemistry, 25(10), 1261-1264.

4. Krishna, P. M., \& Reddy, K. H. (2009). Synthesis, single crystal structure and DNA cleavage studies on first 4 $\mathrm{N}$-ethyl substituted three coordinate copper (I) complex of thiosemicarbazone. Inorganica Chimica Acta, 362(11), 4185-4190.

5. Abou Sekkina, M. M. A., Kashar, T. I., \& Aly, S. A. (2011). Spectrochemical study and effect of high energatic gamma ray on copper(II) complexes. Solid State Sciences, 13(12), 2080-2085.

6. Abou Sekkina, M.M. El-Boraey, H. A., \& Aly, S. A. (2014). Further studies on the properties and effect of high energetic ionizing radiation on copper(II) complexes: ${ }^{1} \mathrm{H}$ NMR, electronic absorption, ESR spectra and solid electrical conductivity. Journal of Radioanalytical and Nuclear Chemistry, 300(2), 867-872.

7. Aly, S. A., and Elembaby, D. (2020) : Synthesis, spectroscopic characterization and Study the effect of gamma irradiation on $\mathrm{VO}^{2+}, \mathrm{Mn}^{2+}, \mathrm{Zn}^{2+}, \mathrm{Ru}^{3+}, \mathrm{Pd}^{2+}, \mathrm{Ag}^{+}$and $\mathrm{Hg}^{2+}$ complexes and antibacterial activities. Arbian, J. 13, 4425-4447.

8. Hanaa.A. El-Boraey, M.A. Abdel-Hakeem, Facile synthesis, spectral, EPR, XRD and antimicrobial screening of some $\gamma^{-}$- irradiated N', N"'-(1E, 2E)-1,2-diphenylethane-1,2-diylidene)bis(2aminobenzohydrazide) metal complexes. J. Mol. Struct. 1211 (2020) 128086.

9. Hanaa. A. El-Boraey, O. A. El-Gammal, N. G. Abdel Sattar, Impact of gamma ray irradiation on some aryl amide bridged Schiff base complexes: spectral, TGA, XRD and antioxidant property, J. Radioanal. Nucl. Chem. 323 (2020) 241-252.

10. Heba. Alshater, H. A. El-Boraey, A. M.A. Homoda, O. A. EL-Gammal, Improving the surface morphology and crystallite size of isonicotinohydrazide based binuclear $\mathrm{Cr}(\mathrm{III}), \mathrm{Zn}(\mathrm{II})$ and $\mathrm{Sn}(\mathrm{IV})$ complexes after irradiation with $y$-rays. J. Mol. Struct. 1232 (2021) 129985.

11. West, D, (1996). Complexometry with EDTA and related reagents $(46,164)$. BDH Chemicals Limited

12. Wallingford, CT GaussView 5.0, (Gaussian Inc. 2009

13. Wallingford, CT Gaussian 09 rev. A.02, (Gaussian Inc. 2009

14. Aly,S.A., El-Boraey, A.H, (2019). Effect of gamma irradiation on spectral, XRD, SEM, DNA binding, molecular modling and antibacterial property of some (Z)eN-(furan-2-yl)methylene)-2-(phenylamino)acetohydrazide metal(II) complexes. Journal of Molecular Structure 1185 :323-332.

15. Elhalafawy K, Guirgis A, Elkousy S, Rizk N,and Eldourghamy A (2009). Purification and characterization of streptokinase produced by s. pyogens and s. equisimilis .Sci. J. Fac. Sci. Minufia Univ(23), 85-103.

16. El-Boraey H, El-Salamony M, Hathout A,(2016). Macrocyclic [N5] transition metal complexes:synthesis, characterization and biological activities J InclPhenom Macrocycl Chem 86:153-166. 
17. Bayoumi , H.A., Alaghaz ,A.M .A., \& Aljahdali , M .S.(2013). $\mathrm{Cu}(\mathrm{II}), \mathrm{Ni}(\mathrm{II}), \mathrm{Co}(\mathrm{II})$ and $\mathrm{Cr}(\mathrm{III})$ complexes with $\mathrm{N}_{2} \mathrm{O}_{2}$ -chelating Schiff's base ligand incorporating azo and sulfonamide moieties: spectroscopic, electrochemical behavior and thermal decomposition studies. Int. J. Electrochem Sci, (8), 9399-9413 .

18. Kong D, Xie Y. (2002).Synthesis, structural characterization of tetraazamacrocyclic ligand, five-coordinated zinc(II) complexes. Inorg Chim Acta. , 338, 142-148.

19. Geary, W.G. (1971). The use of conductivity measurements in organic solvents for the characterization of coordination compounds. Coord Chem Rev.,7,81-122.

20. Aly, S.A. (2017). Spectrochemical Study the Effect of High Energetic Ionization Radiation on $\operatorname{Ru}($ III), Pd( II) and $\mathrm{Hg}(\mathrm{II})$ Complexes.. Journal of Radiation Research and Applied Science, 10, 89-96.

21. AbouSekkina, M. M. A., Kashar, T. I., \& Aly, S. A. (2011). Spectrochemical study and effect of high energatic gamma ray on copper(II) complexes. Solid State Sciences, 13(12), 2080-2085.

22. Nakamoto, K. (1970). Infrared spectra of inorganic and coordination compounds.New alicyclic thiosemicarbazone chelated zinc (II) antitumor complexes: Interactions with DNA/protein, nuclease activity and inhibition of topoisomerase-I. Polyhedron, 105, 89-95.

23. El-Boraey, H. A., El-Salamony, M. A., \& Hathout, A. A. (2016). Macrocyclic $\left[\mathrm{N}_{5}\right]$ transition metal complexes: synthesis, characterization and biological activities. Journal of Inclusion Phenomena and Macrocyclic Chemistry, 86(1-2), 153-166.

24. Aly, S.A. (2017). Spectrochemical Study the Effect of High Energetic Ionization Radiation on $\mathrm{Ru}(\mathrm{III}), \mathrm{Pd}(\mathrm{II})$ and $\mathrm{Hg}$ (II) Complexes.. Journal of Radiation Research and Applied Science, 10, 89-96.

25. Seena, E. B., \& Kurup, M. P. (2008). Synthesis, spectral and structural studies of zinc(II) complexes of salicylaldehyde N (4)-phenylthiosemicarbazone. Spectrochimica Acta Part A: Molecular and Biomolecular Spectroscopy, 69(3), 726-732.

26. Rafi, U. M., Mahendiran, D., Kumar, R. S., \& Rahiman, K. (2019). Metal complexes of tetradentate azo-dye ligand derived from 4,4'-oxydianiline: Preparation, structural investigation, biological evaluation and MOE studies .Appl.Organomet. Chem. 33(7), e4946-4966.

27. Pathaw, L., Maheshwaran, D., Nagendraraj, T., Khamrang, T., Velusamy, M., \& Mayilmurugan, R. (2021). Tetrahedral copper(I) complexes of novel N,N-bidentate ligands and photophysical properties Inorganica Chimica Acta,514, 119999.

28. Ahmed, M., Khalid, W.Y., \& Zain, A.( 2012) Synthesis and Characterization of new thio-Triazole ligand and complexes with selected metals. J. Pharma. Biol. Sci., 4, 09.

29. Sharma, M., Ganeshpandian, M., Majumder, M., Tamilarasan, A., Sharma, M., Mukhopadhyay,R., Islam, Nashreen S. \& Palaniandavar, M . (2020). Octahedral copper(II)-diimine complexes of triethylenetetramine: effect of stereochemical fluxionality and ligand hydrophobicity on Cull/Cul redox, DNA binding and cleavage, cytotoxicity and apoptosis-inducing ability. Dalton Trans., 49, 8282-8297.

30. Leblanc ,M., Gonzalez-Sarrias ,A.,' Beckford, F. A., Mbarushimana ,P. C. \& Seeram, P. N. (2011). Coordination Chemistry of Polyaromatic Thiosemicarbazones 2: Synthesis and Biological Activity of Zinc, Cobalt, and Copper Complexes of 1-(Naphthalene-2-yl)ethanone Thiosemicarbazone. International Journal of Inorganic Chemistry ,2011, Article ID 624756, 1-8 .

31. Paira, M. K., Dinda, J., Lu, T. H., Paital, A. R. \& Sinha, C. (2007). Zn (II), Cd (II) and Hg (II) complexes of 8aminoquinoline.: Structure, spectra and photoluminescence property. Polyhedron, 26(15), 4131-4140. 
32. Azam, M., Al-Resayes, S. I., \& Pallepogu, R. (2016). Synthesis and Structural Characterization of Cadmium (II) and Mercury (II) Complexes Derived from 3-Aminoquinoline. Helvetica Chimica Acta, 99(1), 20-23.

33. Sen, S., Saha, M. K., Kundu, P., Mitra, S., Kruger, C., \&Bruckmann, J. (1999). Synthesis and structure of a heptacoordinated cadmium (II) complex. Inorganica chimica acta, 288(1), 118-121.

34. Huang,B. L., Perez, R. J., Lavernia, E. J., \& Luton, M. J. (1996). Formation of supersaturated solid solutions by mechanical alloying. Nanostructured Materials, 7(1), 67-79.

35. Al-Ashqer, S., Abou-Melha, K. S., Al-Hazmi, G. A. A., Saad, F. A., \& El-Metwaly, N. M. (2014). Spectral studies on a series of metal ion complexes derived from pyrimidine nucleus, TEM, biological and $\mathrm{Y}$-irradiation effect. Spectrochimica Acta Part A: Molecular and Biomolecular Spectroscopy, 132, 751-761.

36. Jayashri, T. A., Krishnan, G., \& Rema Rani, N. (2014). Effect of gamma-irradiation on thermal decomposition kinetics, X-ray diffraction pattern and spectral properties of tris (1, 2-diaminoethane) nickel(II) sulphate. Radiation Effects and Defects in Solids, 169(12), 1019-1030.

37. Jeslin Kanaga Inba, P., Annaraj, B., Thalamuthu, S. \&Neelakantan, M. A. (2013). Cu (II), Ni (II), and Zn (II) complexes of salan-type ligand containing ester groups: synthesis, characterization, electrochemical properties, and in vitro biological activities. Bioinorganic Chemistry and Applications, 2013.

38. Sharma, A. \& Shah, M. (2013). Synthesis and characterization of some transition metal complexes derived from bidentate Schiff base ligand. Journal of Applied Chemistry, 3, 62-66.

39. Tweedy, B. G. (1964). Plant extracts with metal ions as potential antimicrobial agents. Phytopathology, 55, 910-914.

40. Sönmez, M., Celebi, M., \& Berber, I. (2010). Synthesis, spectroscopic and biological studies on the new symmetric Schiff base derived from 2, 6-diformyl-4-methylphenol with $\mathrm{N}$-aminopyrimidine. European Journal of Medicinal Chemistry, 45(5), 1935-1940.

41. Chohan, Z. H., Shaikh, A. U., Rauf, A., \& Supuran, C. T. (2006). Antibacterial, antifungal and cytotoxic properties of novel N-substituted sulfonamides from 4-hydroxycoumarin. Journal of Enzyme Inhibition and Medicinal Chemistry, 21(6), 741-748.

42. Singh, N. K. (2014). Manganese(II) and zinc(II) complexes of 4-phenyl (2-methoxybenzoyl)-3thiosemicarbazide: Synthesis, spectral, structural characterization, thermal behavior and DFT study. Polyhedron, 73, 98-109.

43. Pisano,M. B., Kum, A., Medda, R., Gianluca Gatto,G., Pal,R., Fais, A., Benedetta Era, B., Cosentino, S., Uriarte, E., Santana,L., Pintus, F., and Matos, M. J. Antibacterial Activity and Molecular Docking Studies of a Selected Series of Hydroxy-3-arylcoumarins Molecules 2019, 24, 2815

44. El-Etrawy, A., Sherbiny, F. F., Design, synthesis, biological assessment and molecular docking studies of some new 2-Thioxo-2,3-dihydropyrimidin-4(1H)-ones as potential anticancer and antibacterial agents, Journal of Molecular Structure, 1225, $5,2021,129014$.

45. Hassan, S. S., Antibacterial, DFT and molecular docking studies of Rh(III) complexes of CoumarinylThiosemicarbazone nuclei based ligands Appl. Organomet. Chem. 2017, 32, 1.

46. Hassan, S. S. and Gomha, S. M., Novel functionalized thiosemicarbazone ligands and their Pd(II) complexes: synthesis, characterization, antibacterial and cytotoxic activities Chem. Pap. 2018, $73,331$.

47. Hassan, S. S. and Mohamed, E. F. Antimicrobial, antioxidant and antitumor activities of Nano Structure Eu(III) and La(III) complexes with nitrogen donor tridentate ligands Appl Organometal Chem. 2020 
48. Khalf-Alla, P. A., Basta, A. H., Lotfy, V. F. and Hassan, S. S. Synthesis, Characterization, Speciation, and Biological Studies on Metal Chelates of Carbohydrates with Molecular Docking Investigation, Macromol. Mater. Eng. 2021, 306.

\section{Figures}

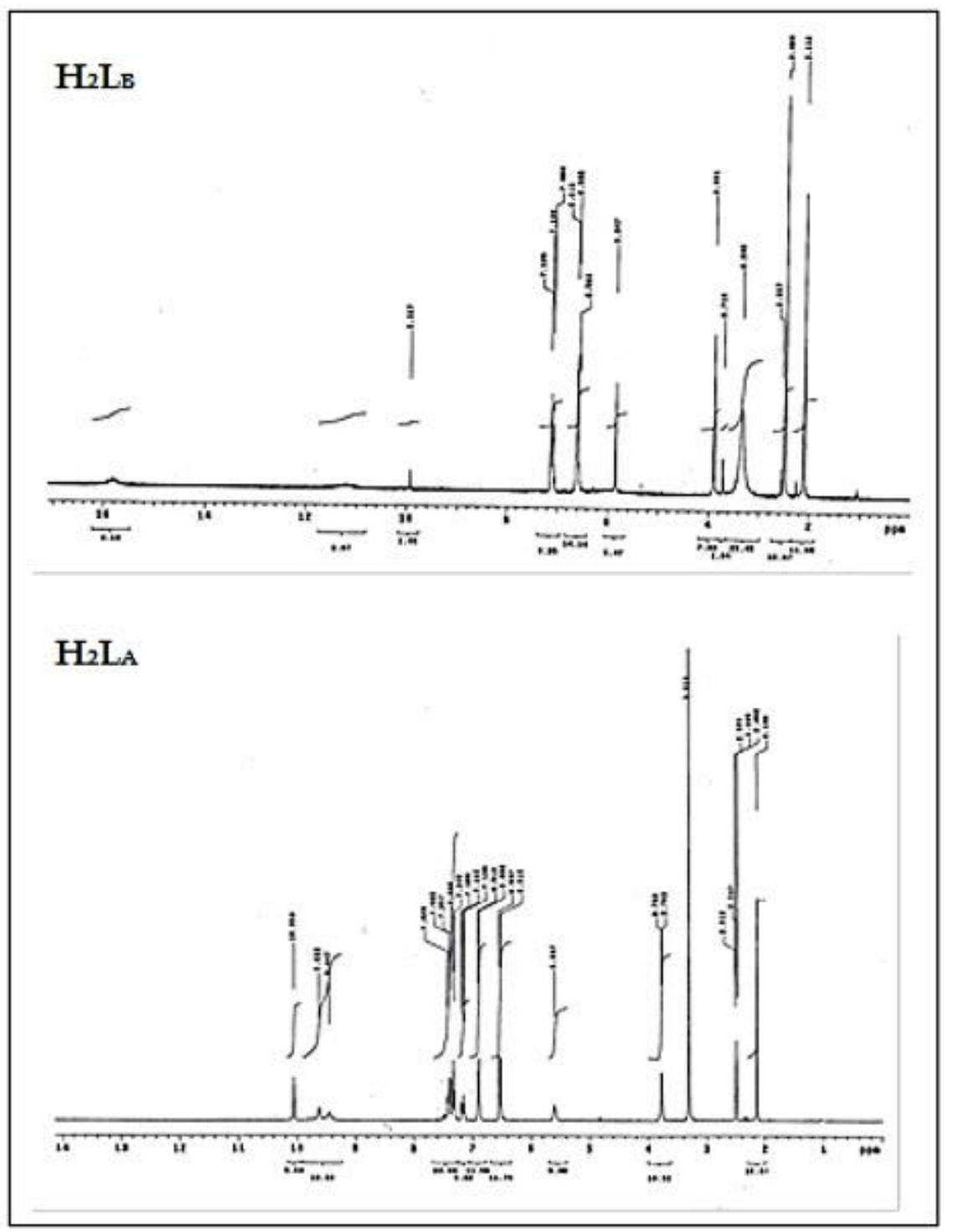

Figure 1

1H NMR spectra of ligands (H2LB) before and after irradiation (H2LA) in DMSO-d6 solution 


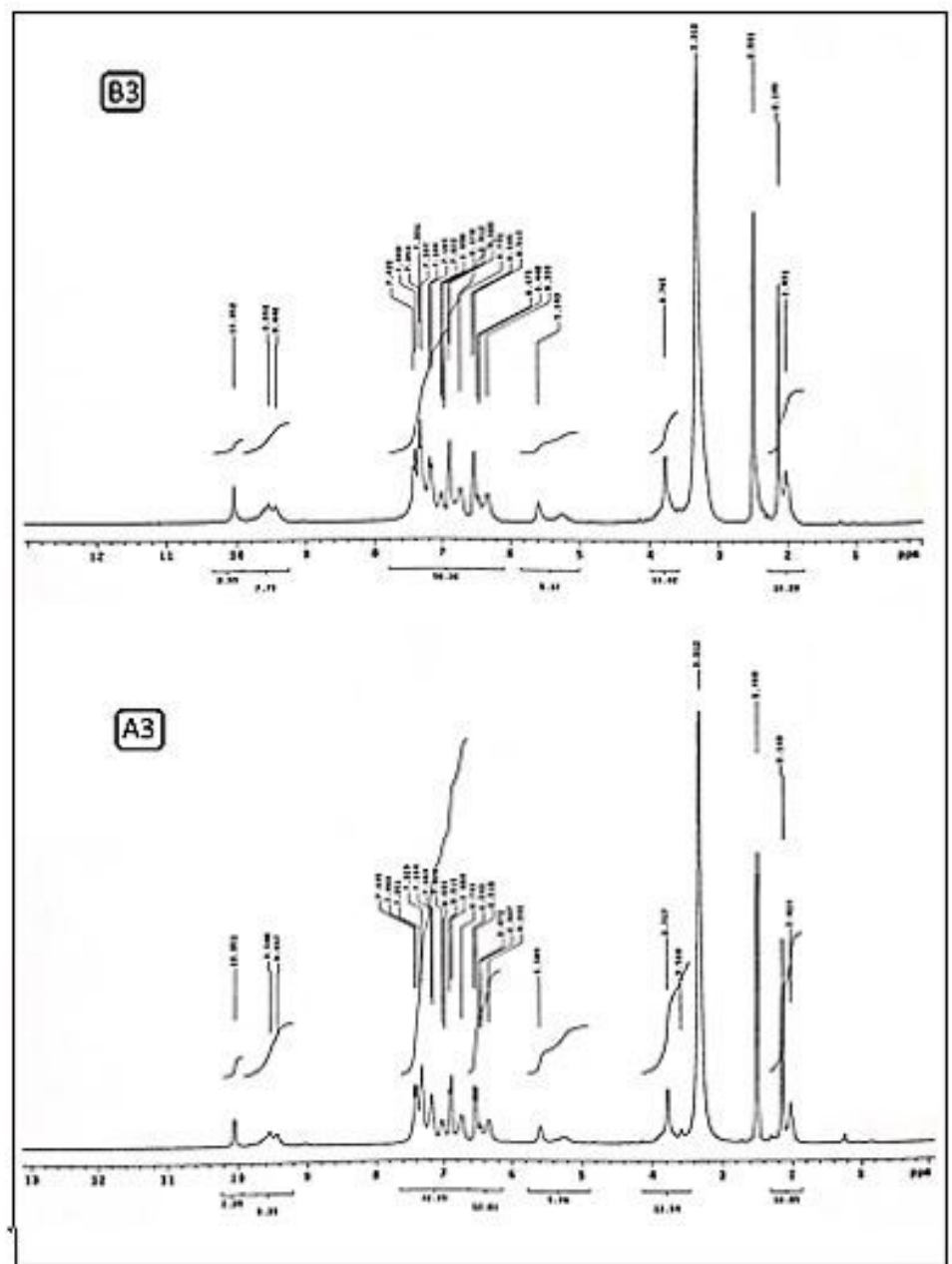

Figure 2

1H NMR spectra of complexes B3 before and after irradiation A3 in DMSO-d6 solution 


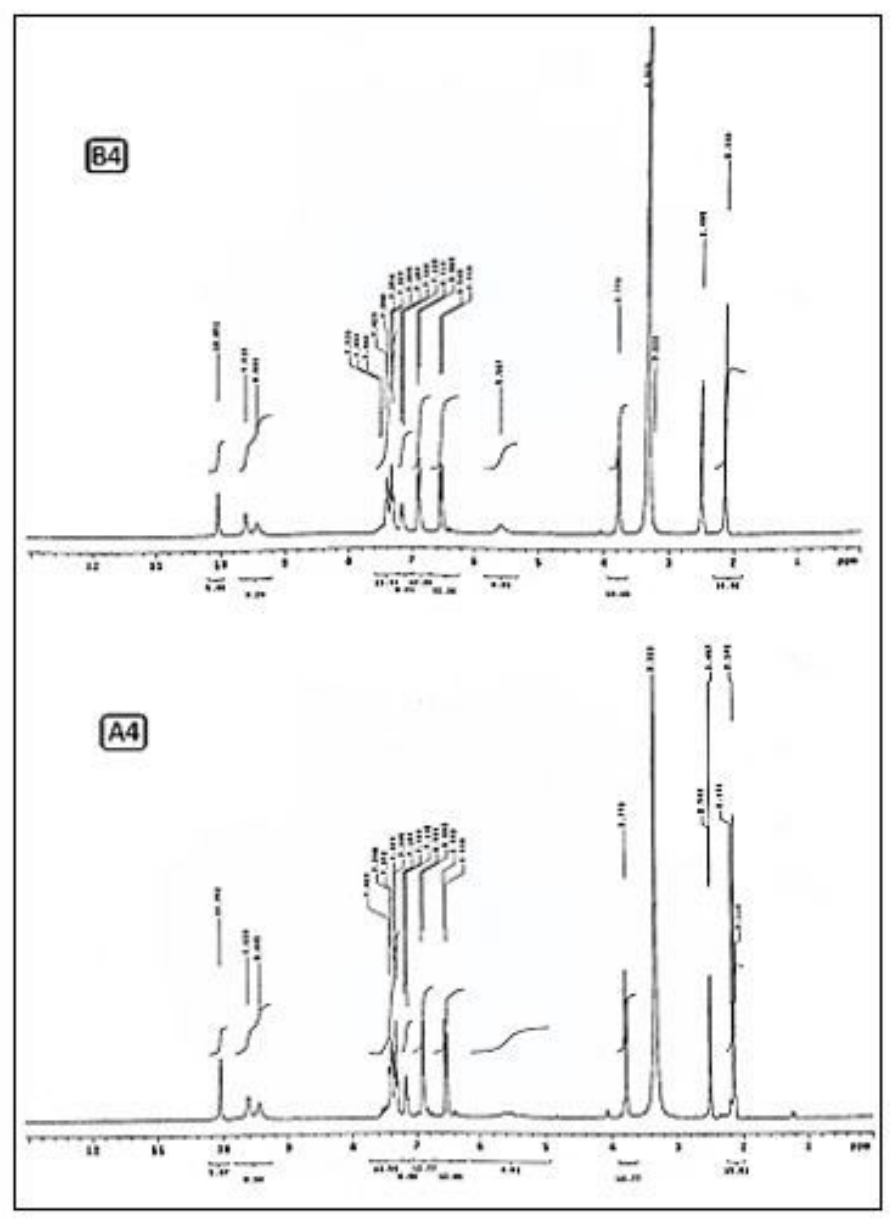

Figure 3

1H NMR spectra of cadium complex (B4) before and after irradiation (A4) in DMSO-d6 solution

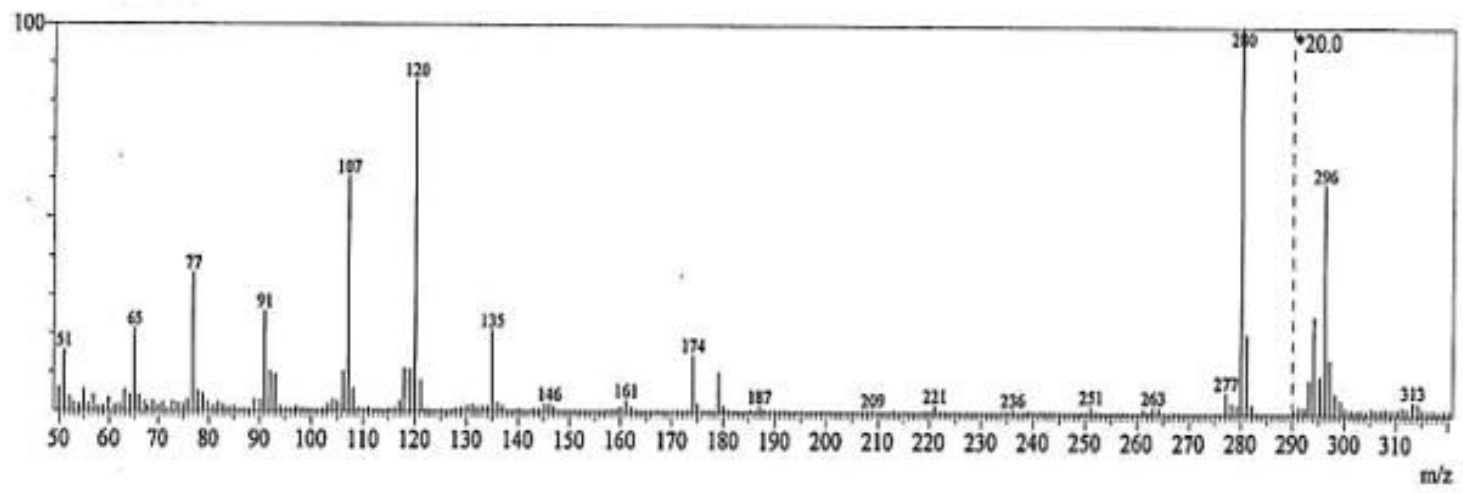

Figure 4

Mass spectrum of ligand (H2LB) 


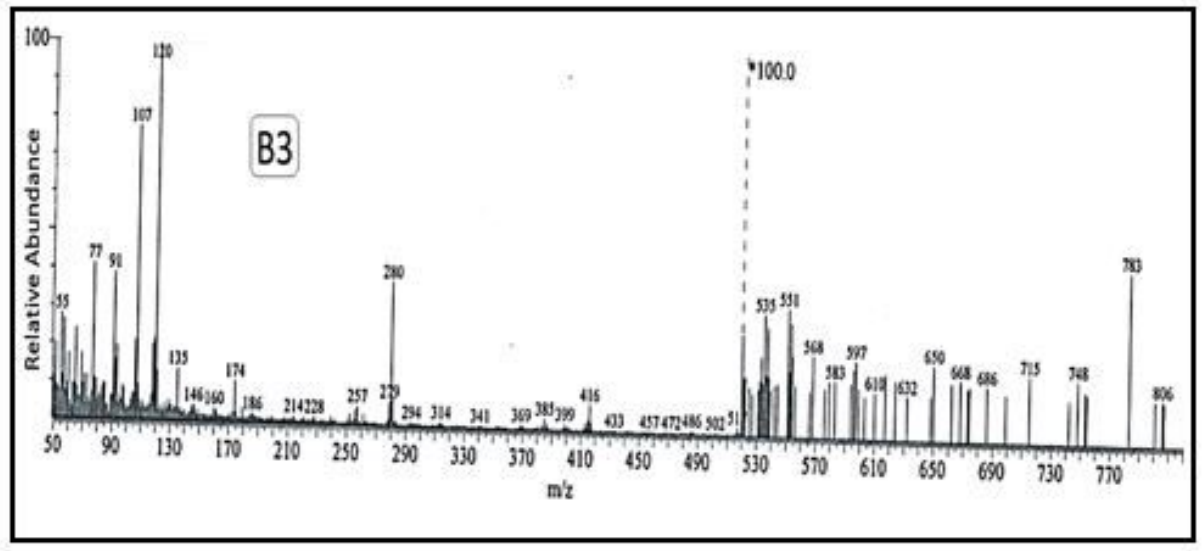

Figure 5

Mass spectrum of zinc complex (B3)

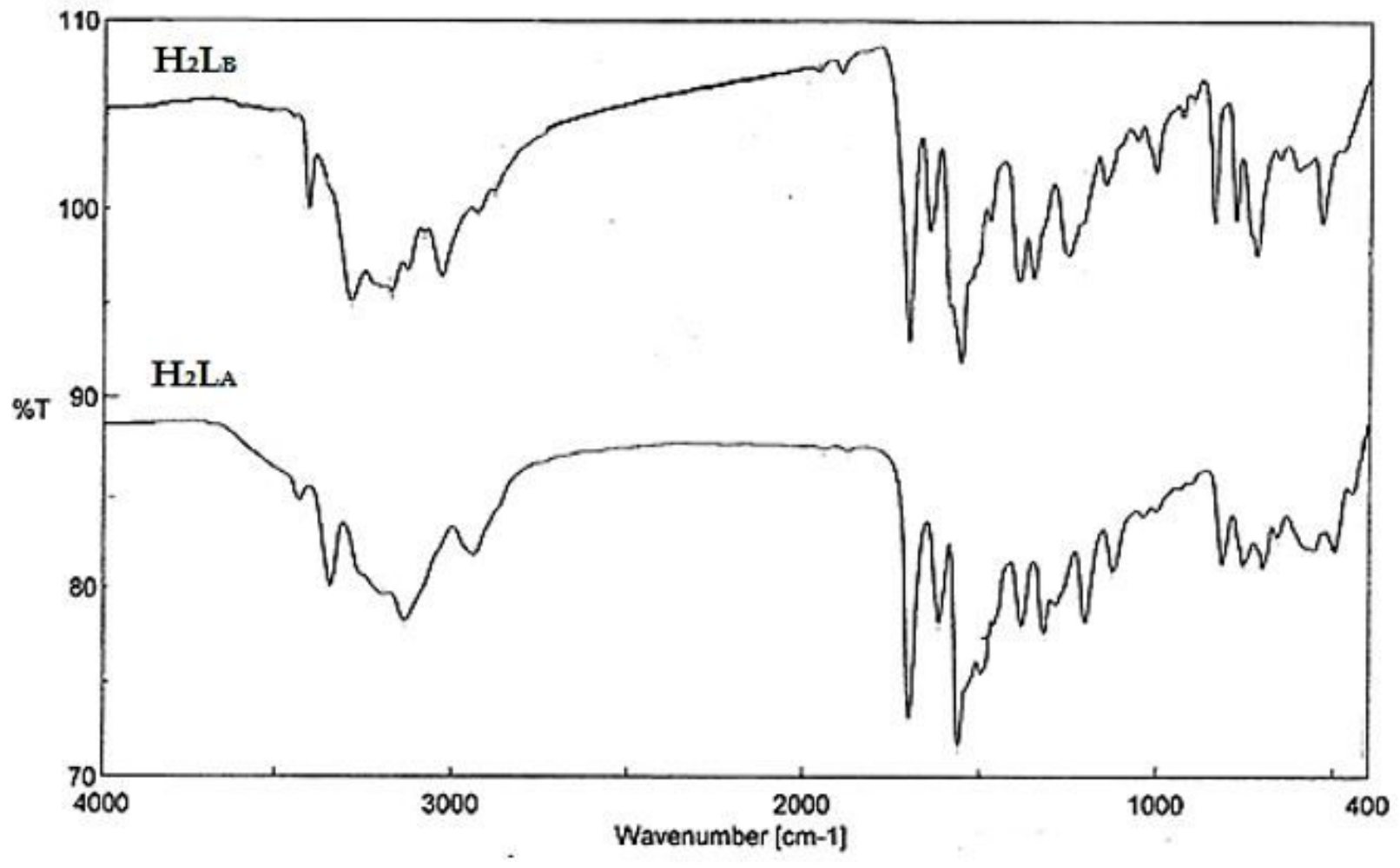

Figure 6

IR spectra of the ligand (H2LB) before irradiation and after irradiation (H2LA) 


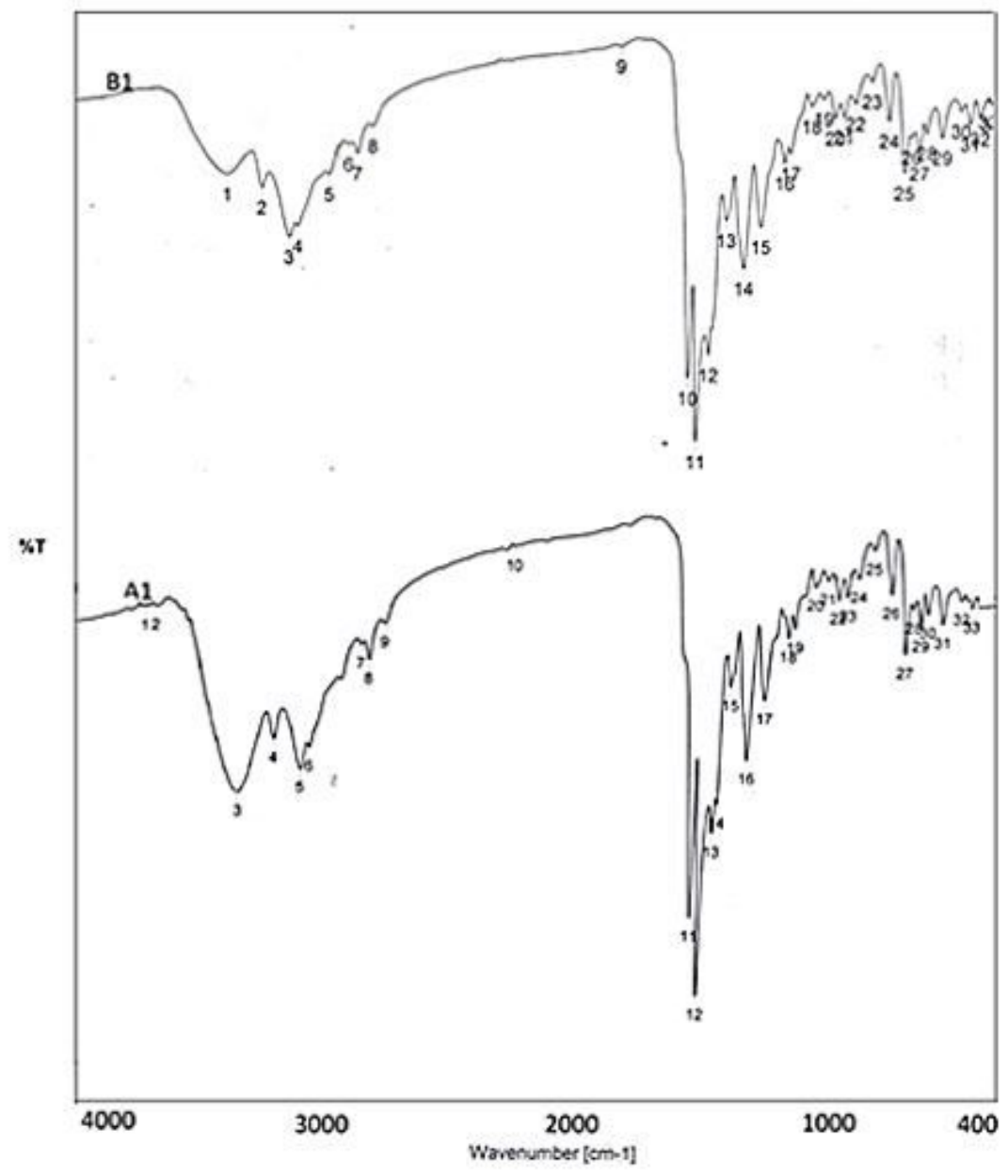

Figure 7

IR spectra of copper(I) complexes before irradiation (B1) and after irradiation (A1) 


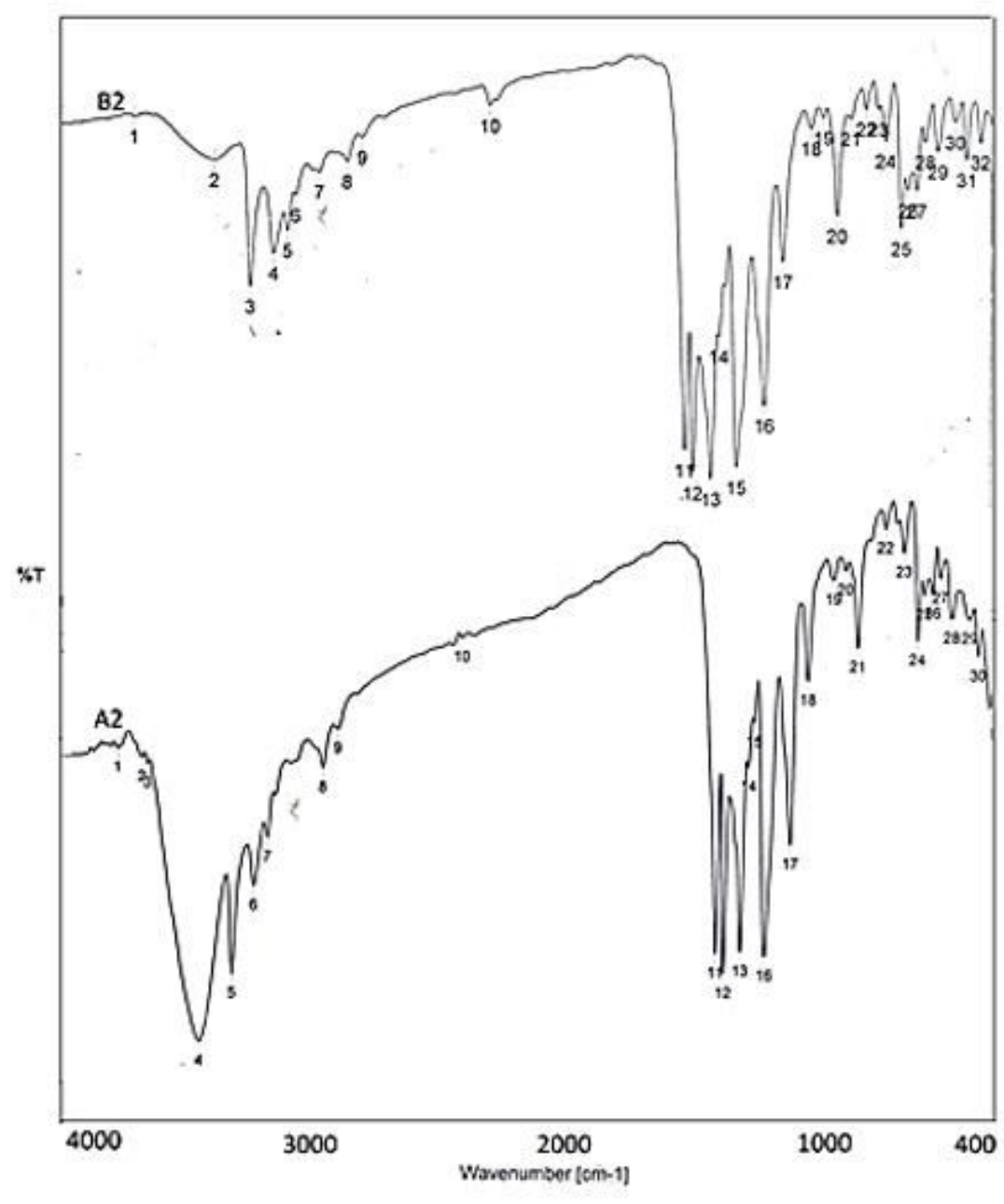

Figure 8

IR spectra of copper(II) complexes before irradiation (B2) and after irradiation (A2) 


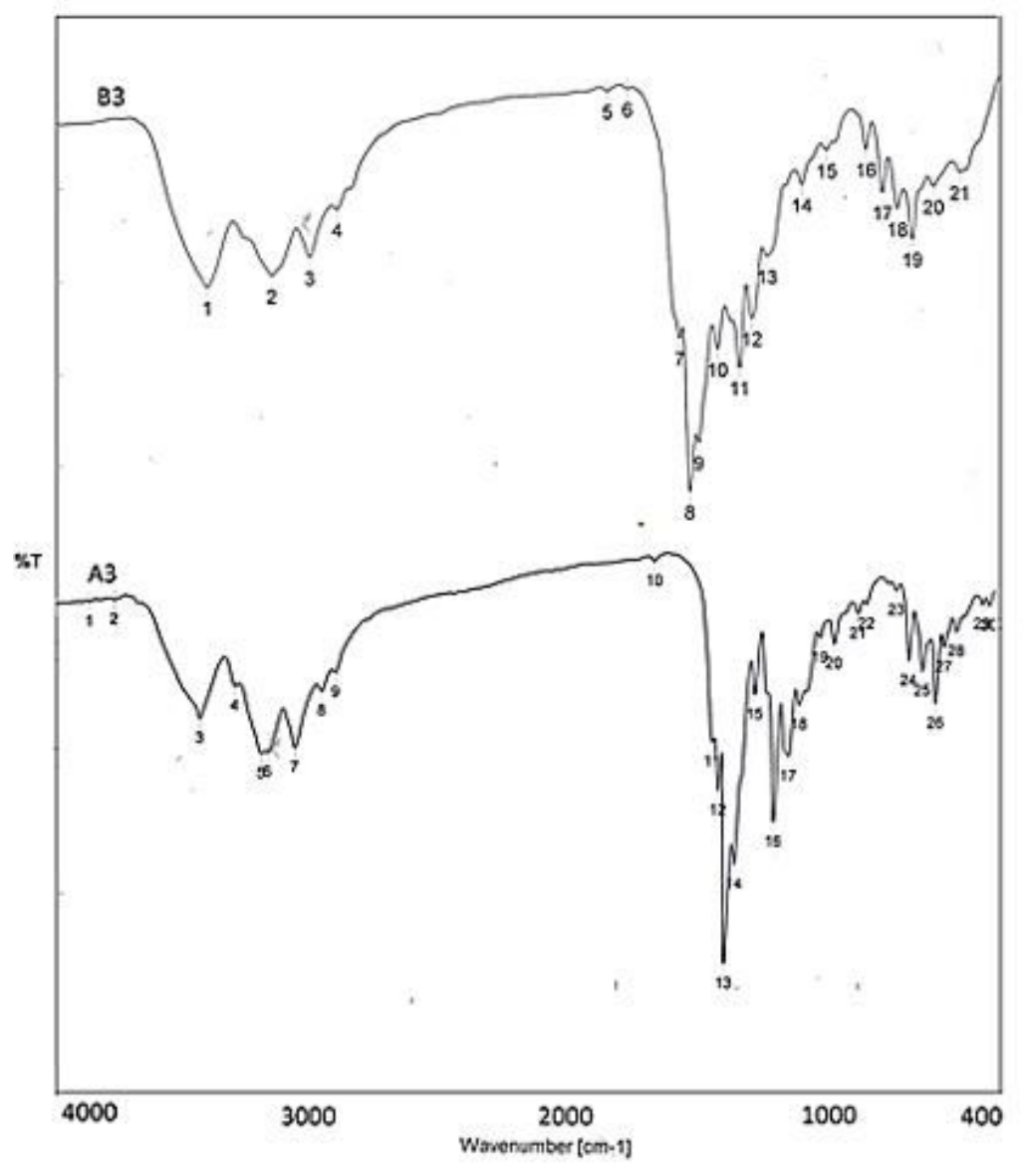

Figure 9

IR spectra of zinc complexes before irradiation (B3) and after irradiation (A3) 


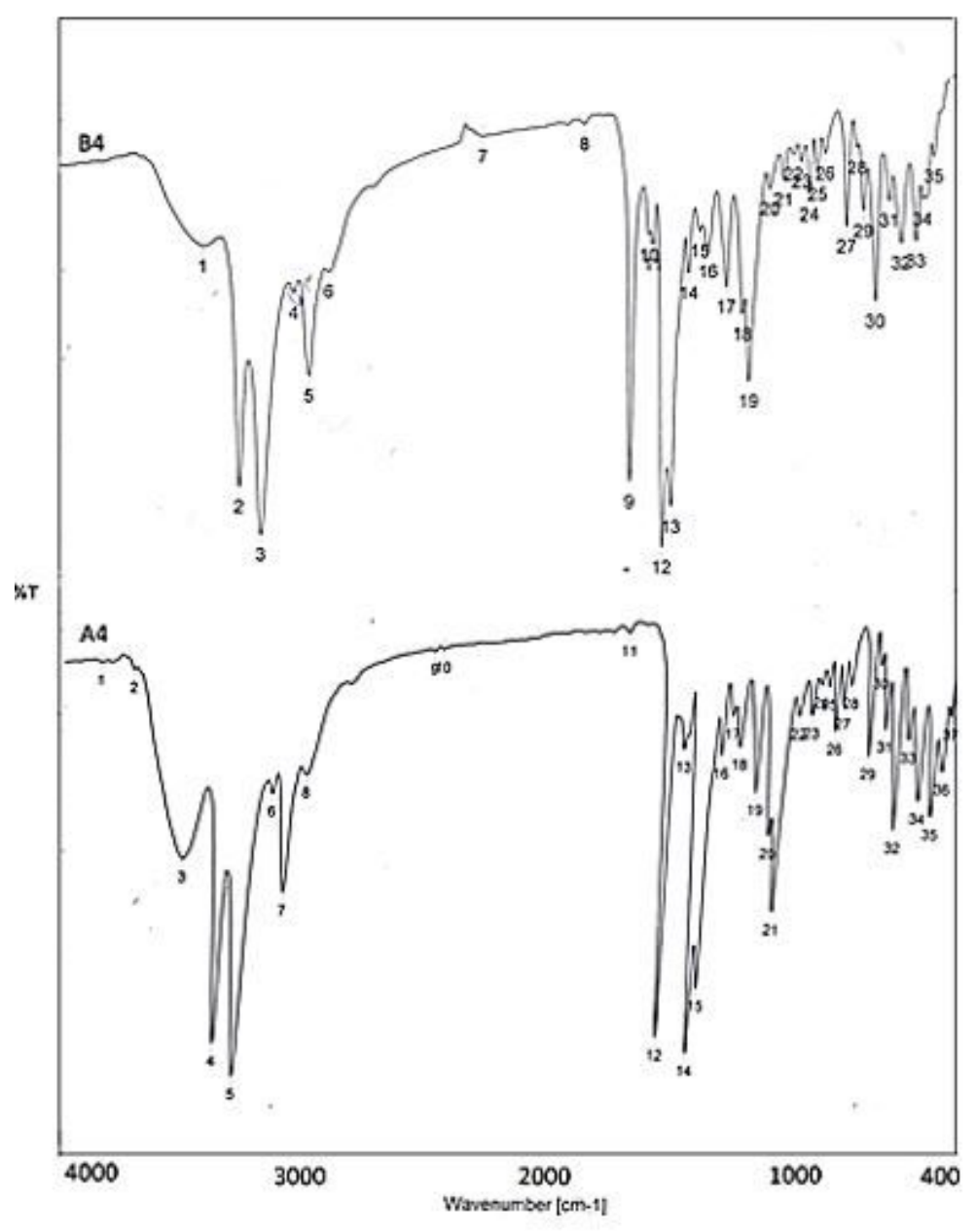

Figure 10

IR spectra of Cadium complexes before irradiation (B4) and after irradiation (A4)

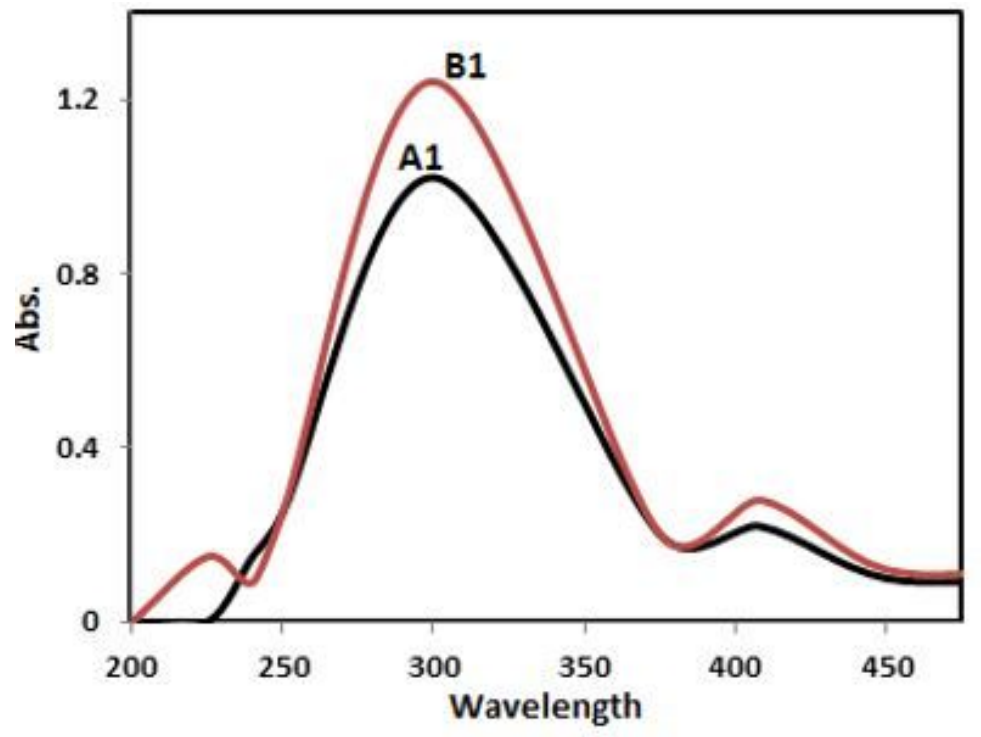

Figure 11

UV- spectra of copper complexes before and after irradiation(B1 and A1) 


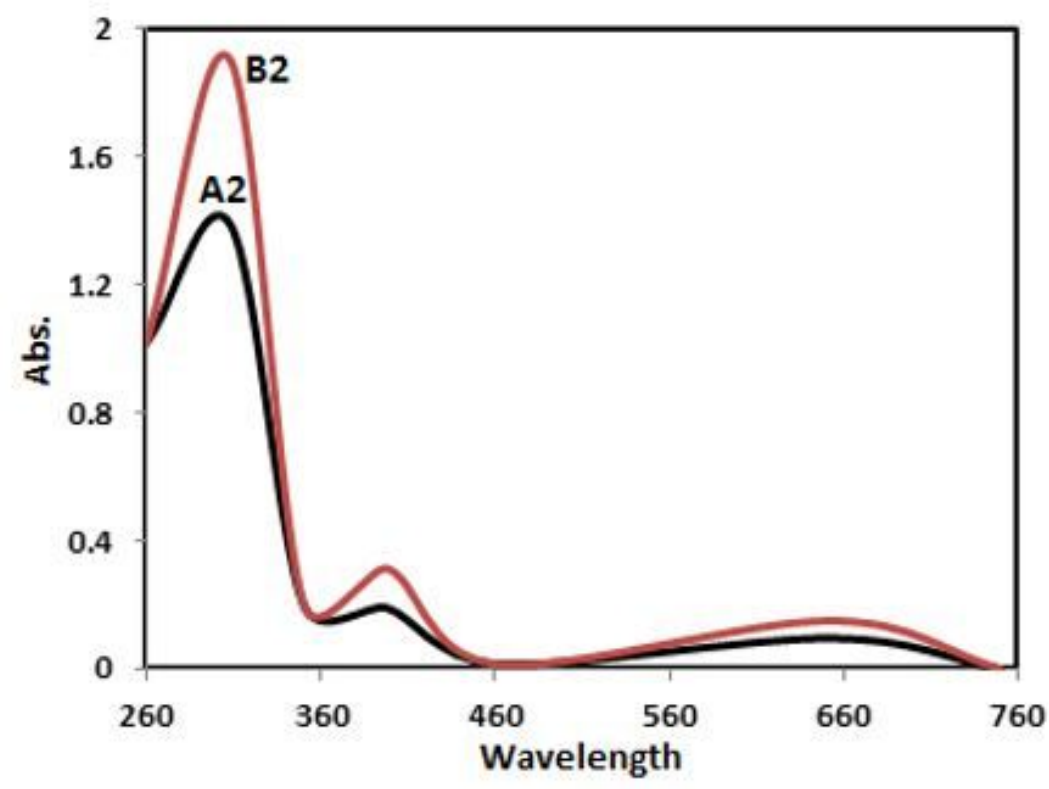

Figure 12

UV- spectra of copper complexes before and after irradiation(B2and A2)

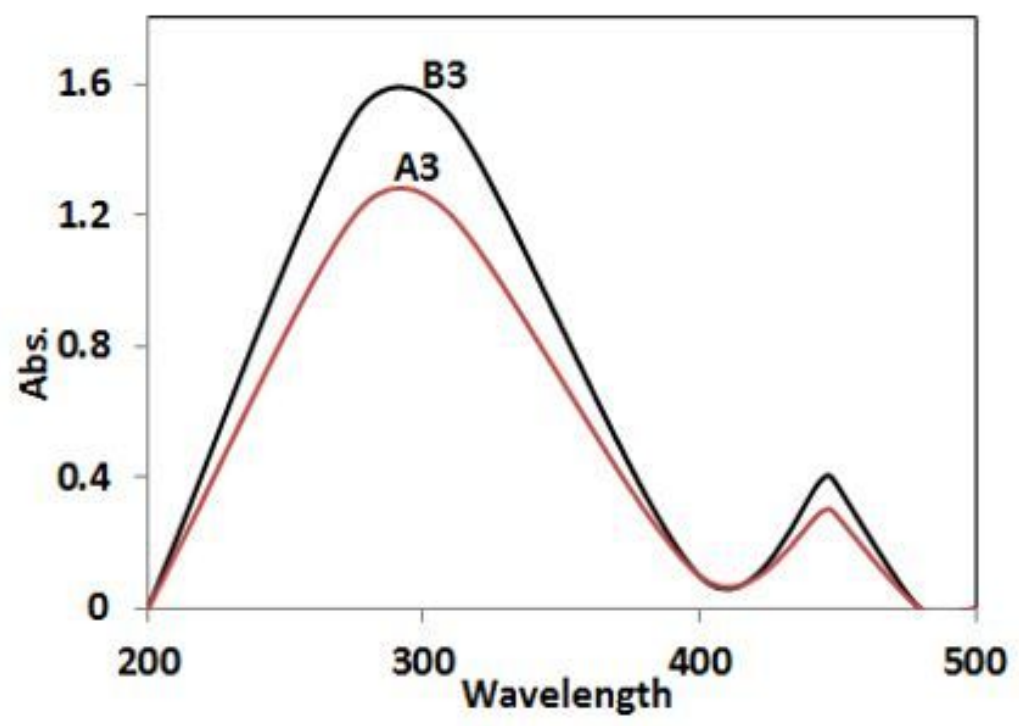

Figure 13

UV- spectra of zinc(II) complexes before and after irradiation(B3and A3) 


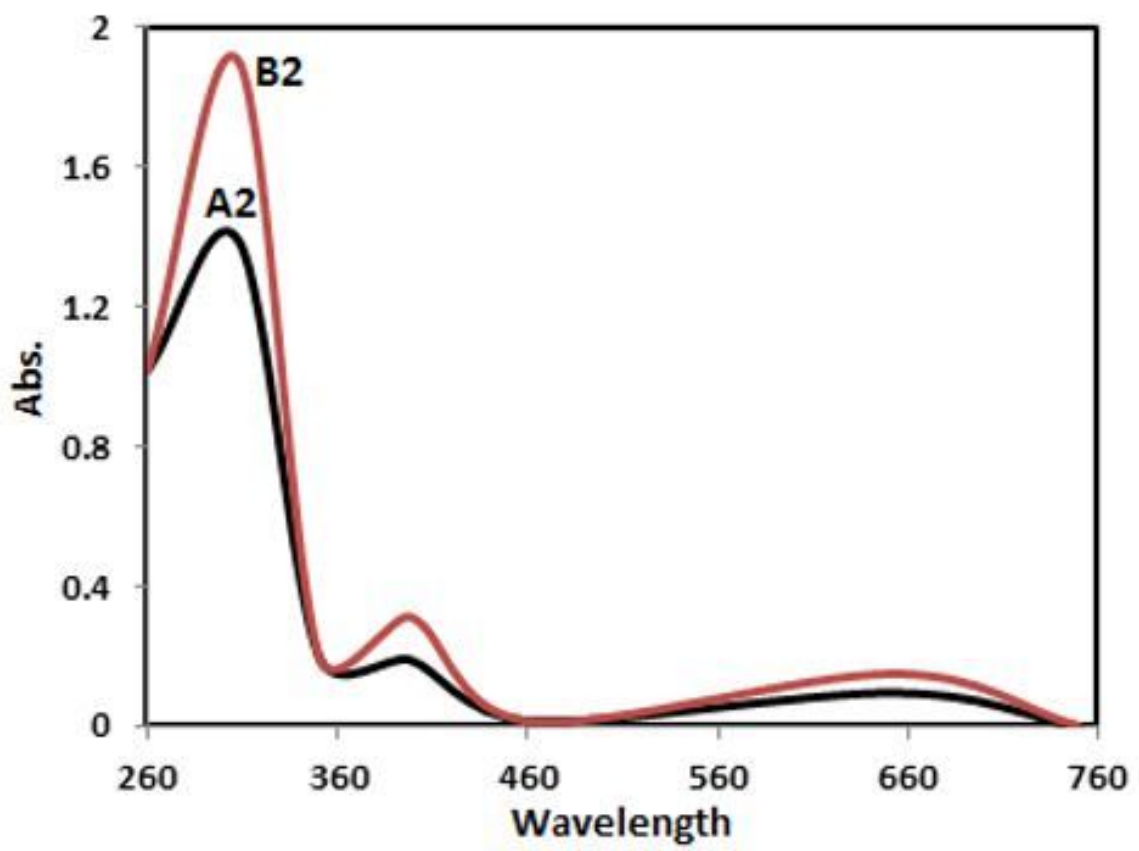

Figure 14

UV- spectra of $\mathrm{Cd}(\mathrm{II})$ complexes before and after irradiation(B4 and A4)

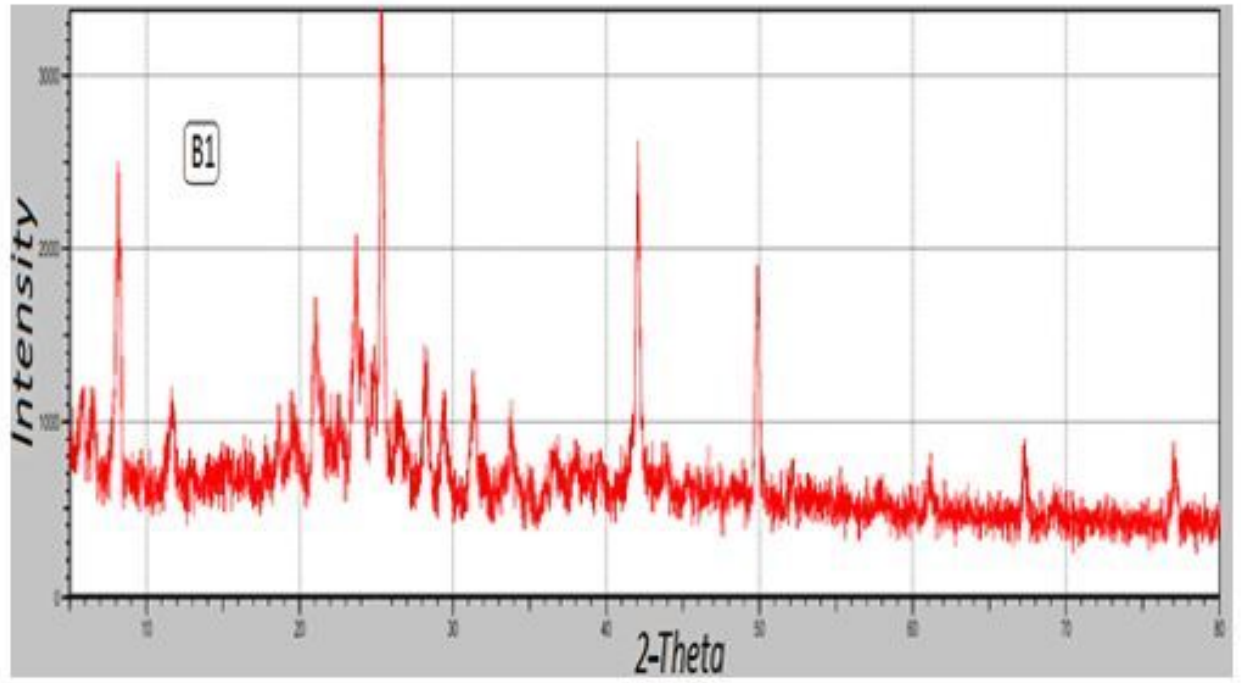

Figure 15

XRD spectra of copper(I) complex before irradiation(B1) 


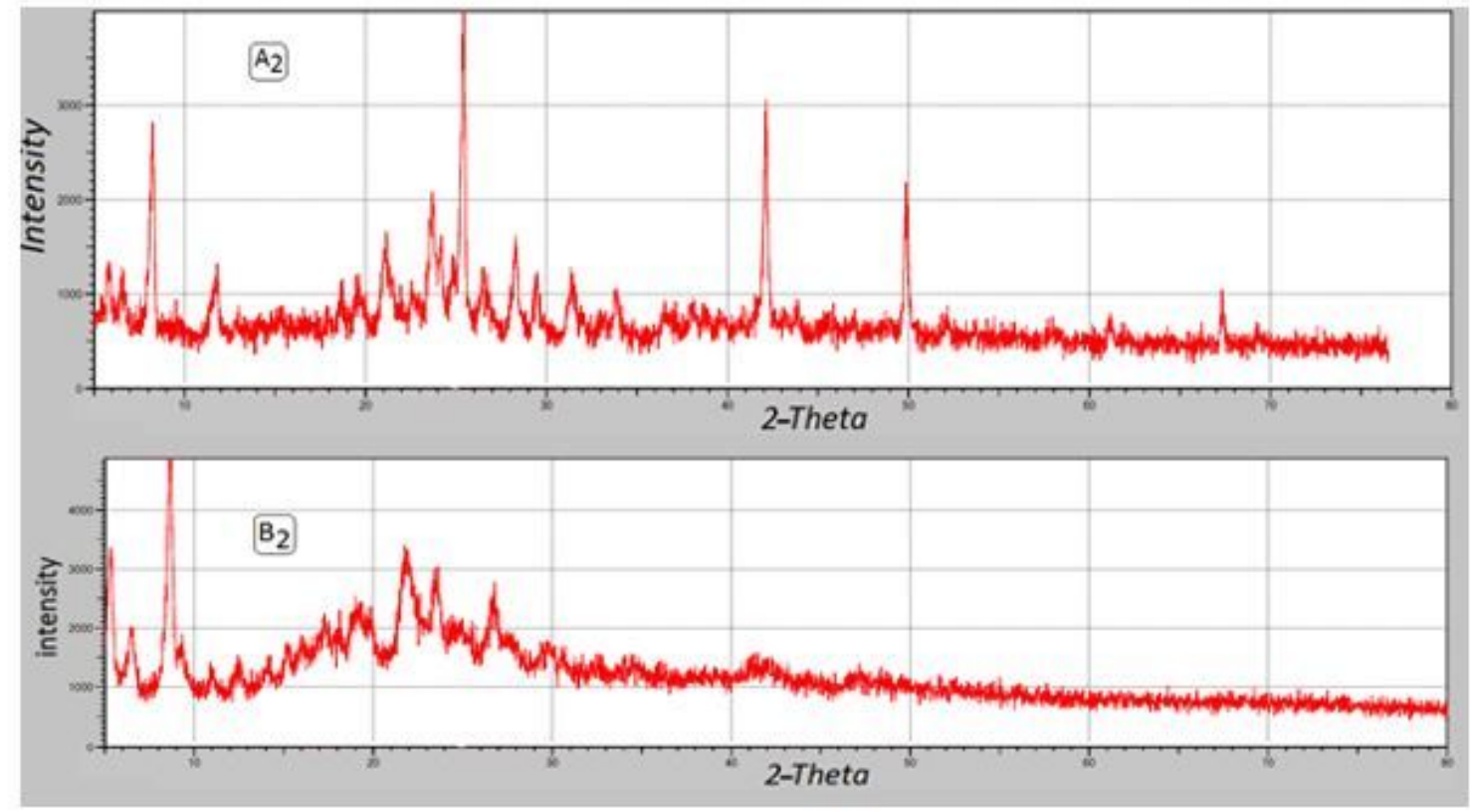

Figure 16

XRD spectra of copper(II) complexes before and after irradiation(B2 and A2)

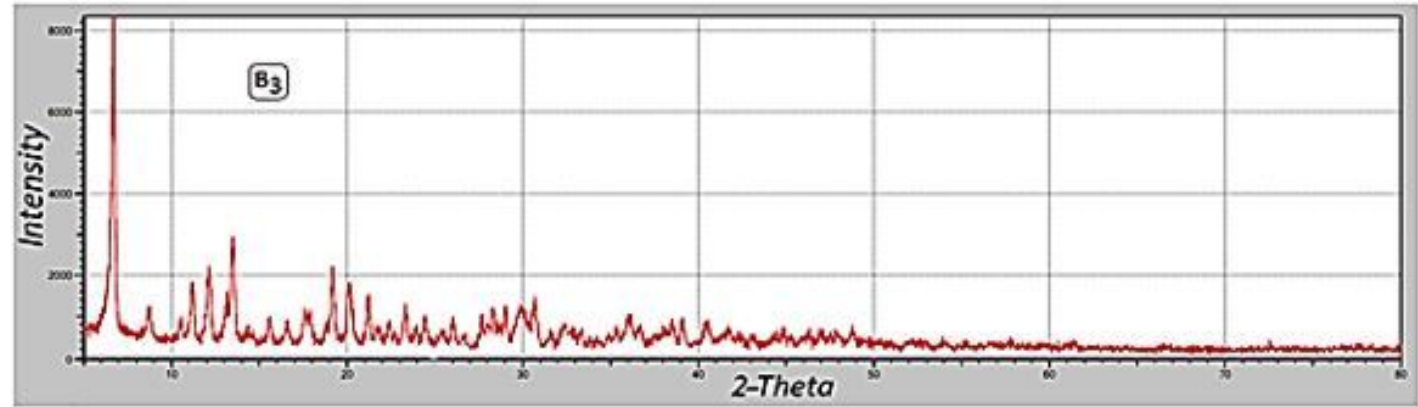

(A)

Figure 17

XRD spectra of zinc(II) complexes before and after irradiation(B3 and A3) 


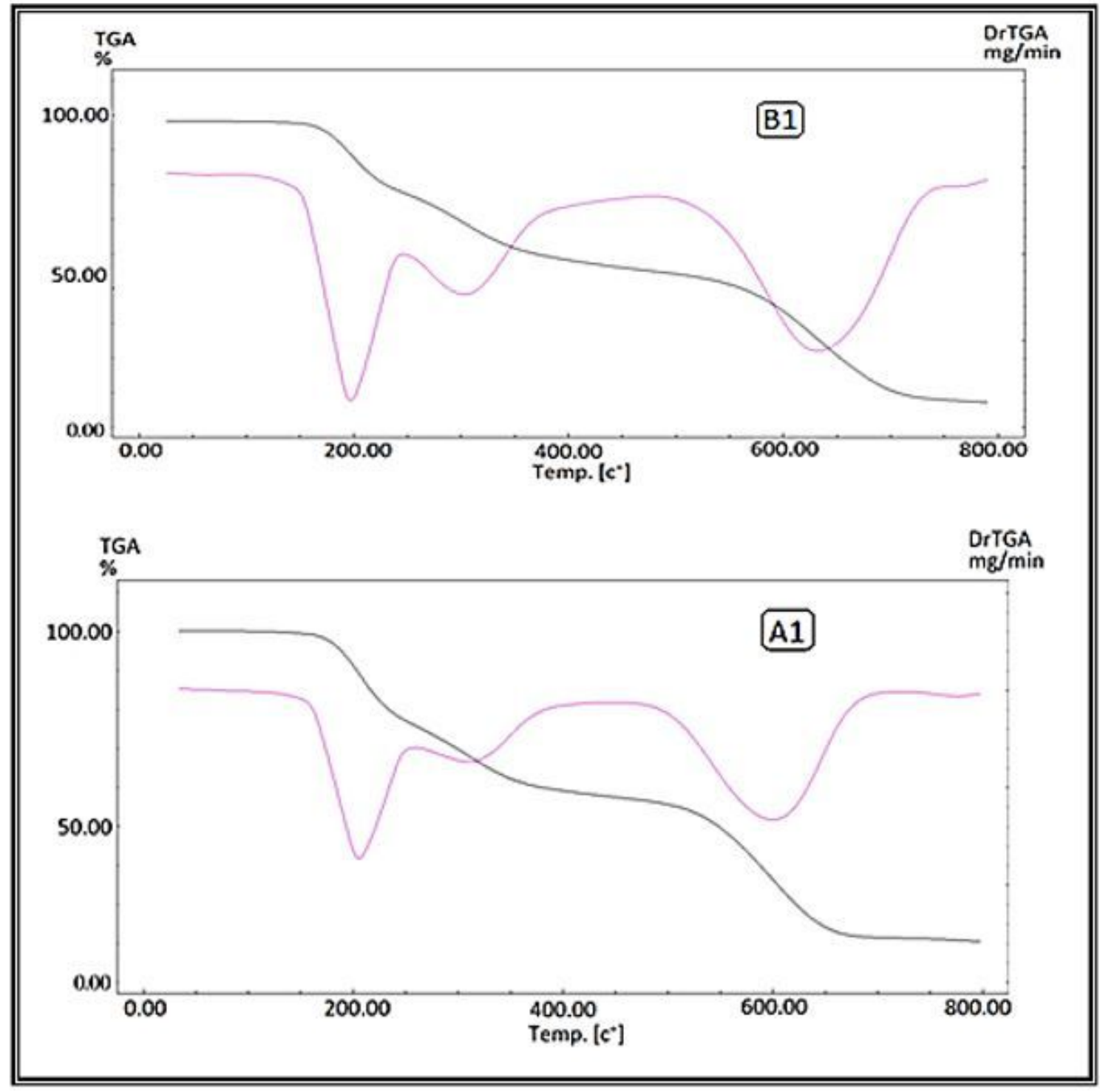

Figure 18

TGA/ DTG curves of complexes before irradiation (B1), after irradiation (A1) 


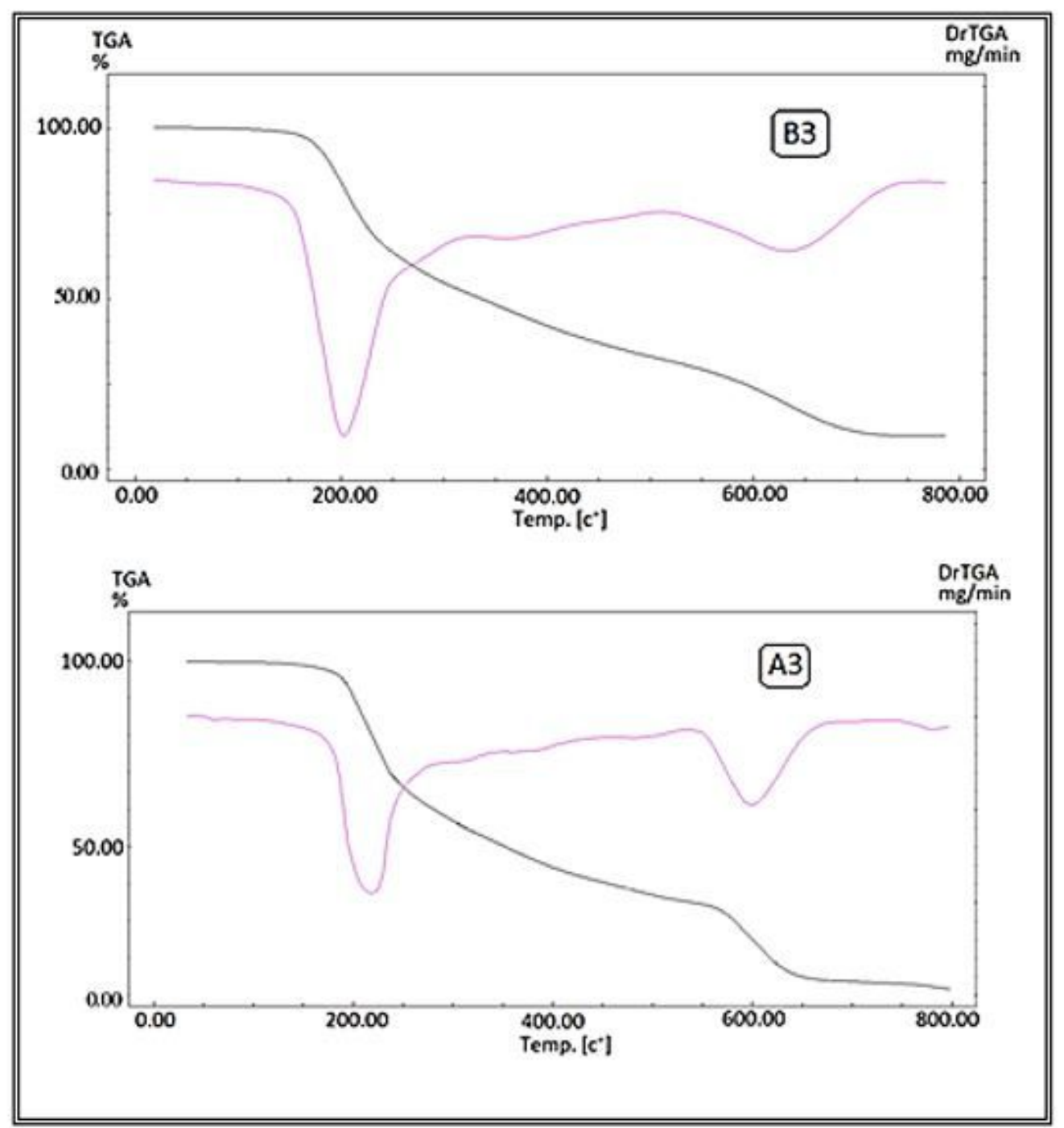

Figure 19

TG/ DTG curves of complexes (B3) before irradiation, after irradiation (A3) 


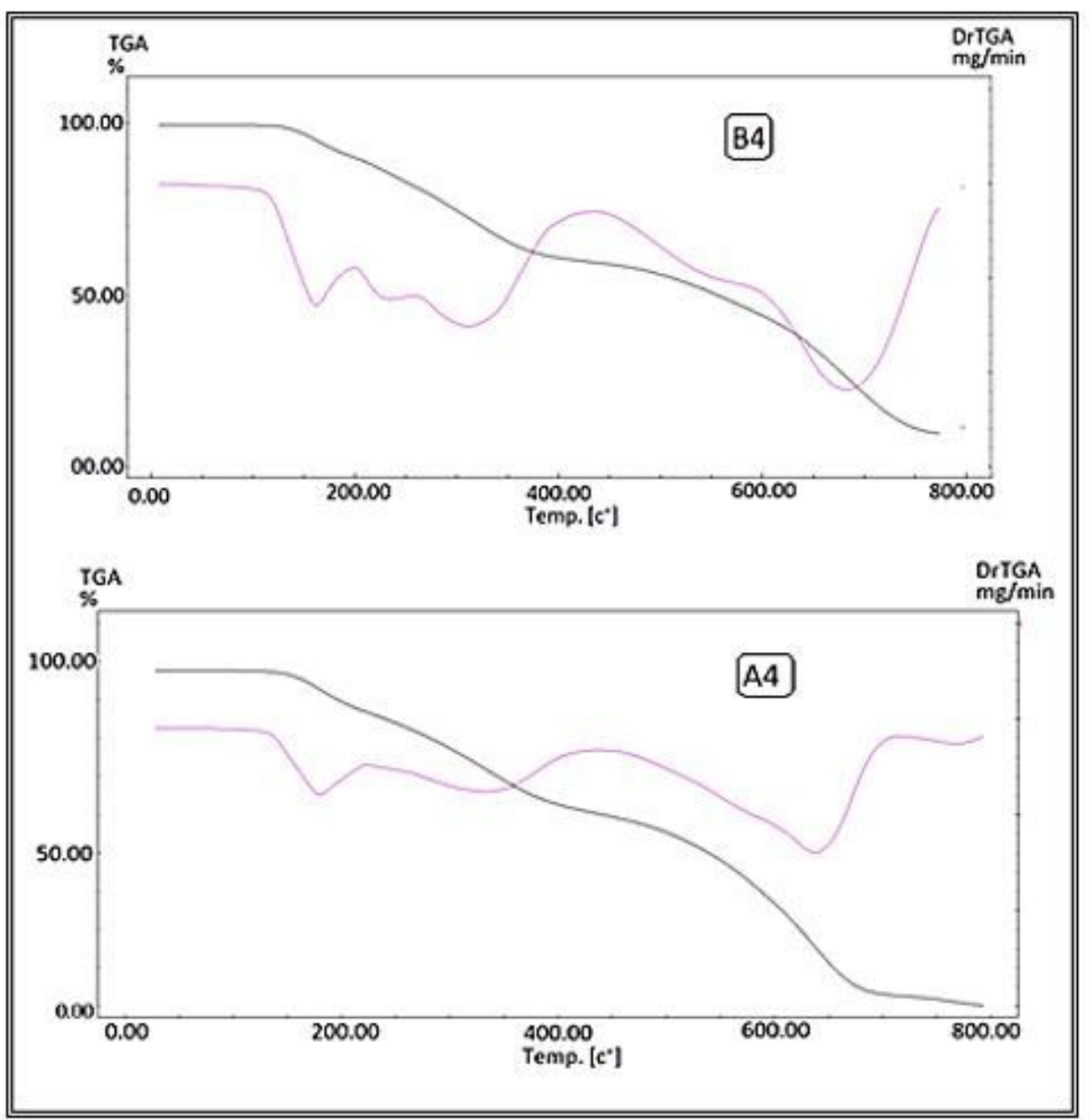

Figure 20

TG/ DTG curves of complexes (B4) before irradiation, after irradiation (A4) 


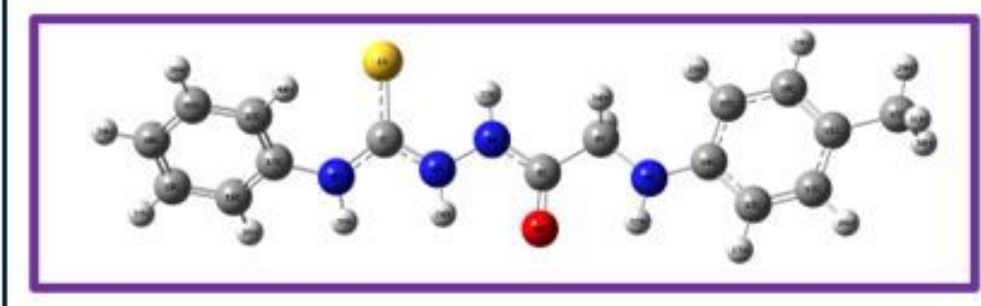

(a) $\mathrm{H}_{2} \mathrm{LB}_{\mathrm{B}}$

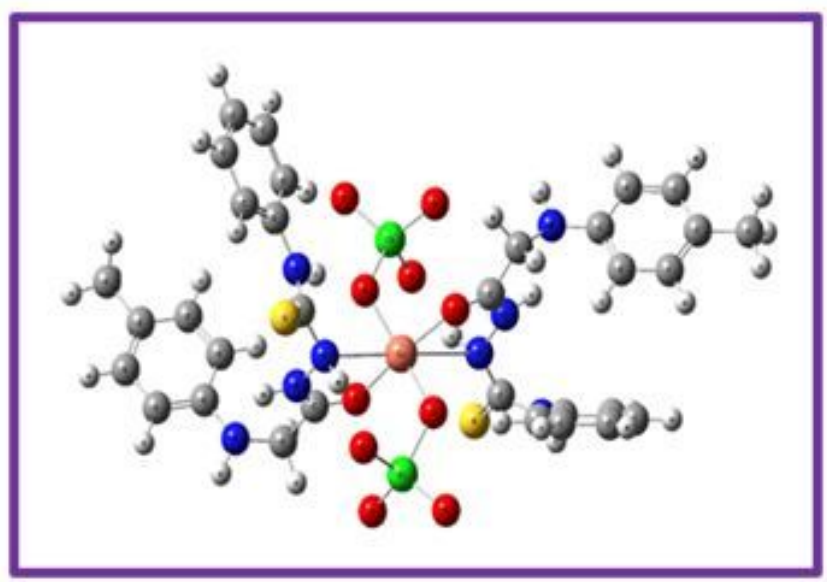

(c) $\mathrm{B}_{2}$

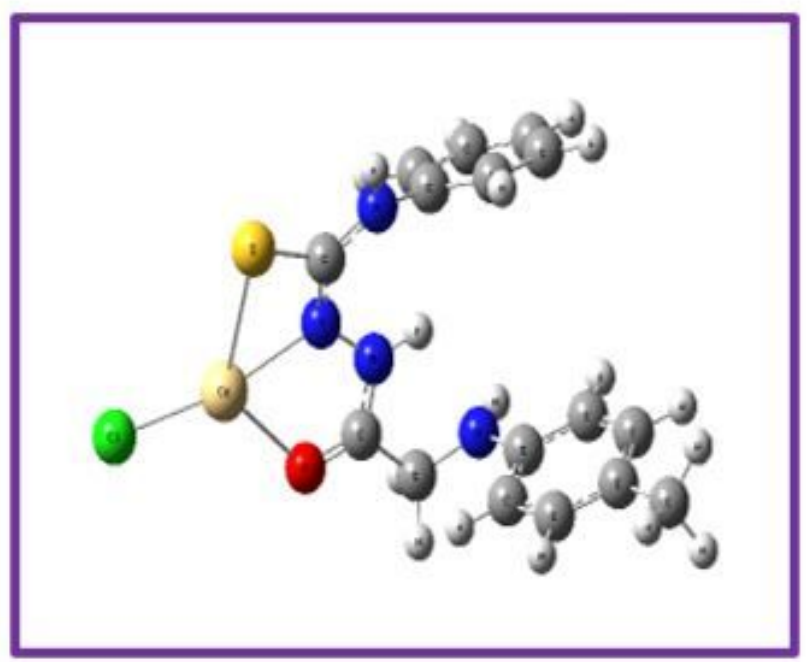

(e) $\mathbf{B}_{4}$

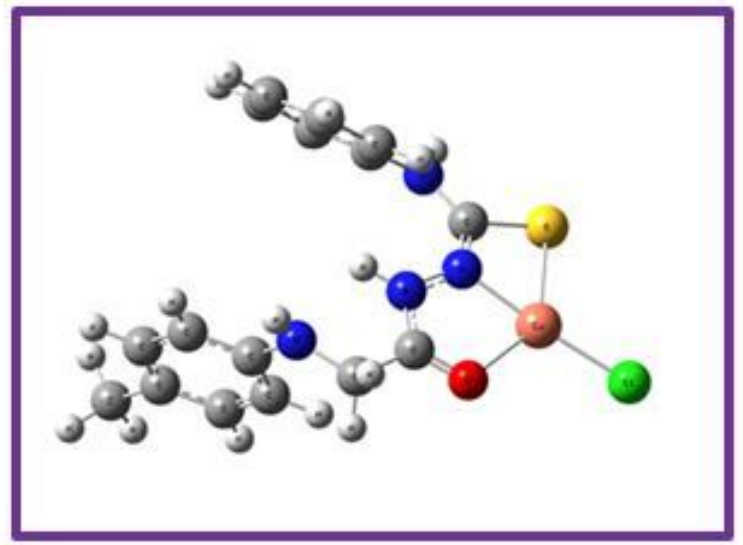

(b) $\mathbf{B}_{1}$

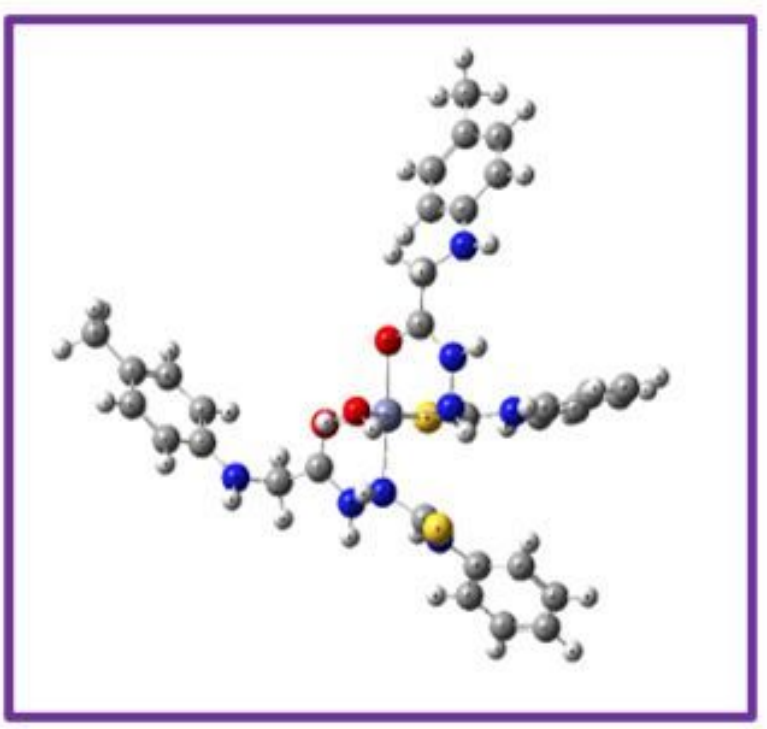

(d) $\mathrm{B}_{3}$

Figure 21

Optimized 3D structures of ligand (a) H2LB, (b) )[Cu(H2L)l], (c) [Cu(H2L)2ClO4], (d) [ $\mathrm{Zn}(\mathrm{H} 2 \mathrm{~L}) 2(\mathrm{H} 2 \mathrm{O})] \mathrm{SO} 4$ and (e ) $[\mathrm{Cd}(\mathrm{H} 2 \mathrm{~L}) \mathrm{Cl}] \mathrm{Cl}$. 


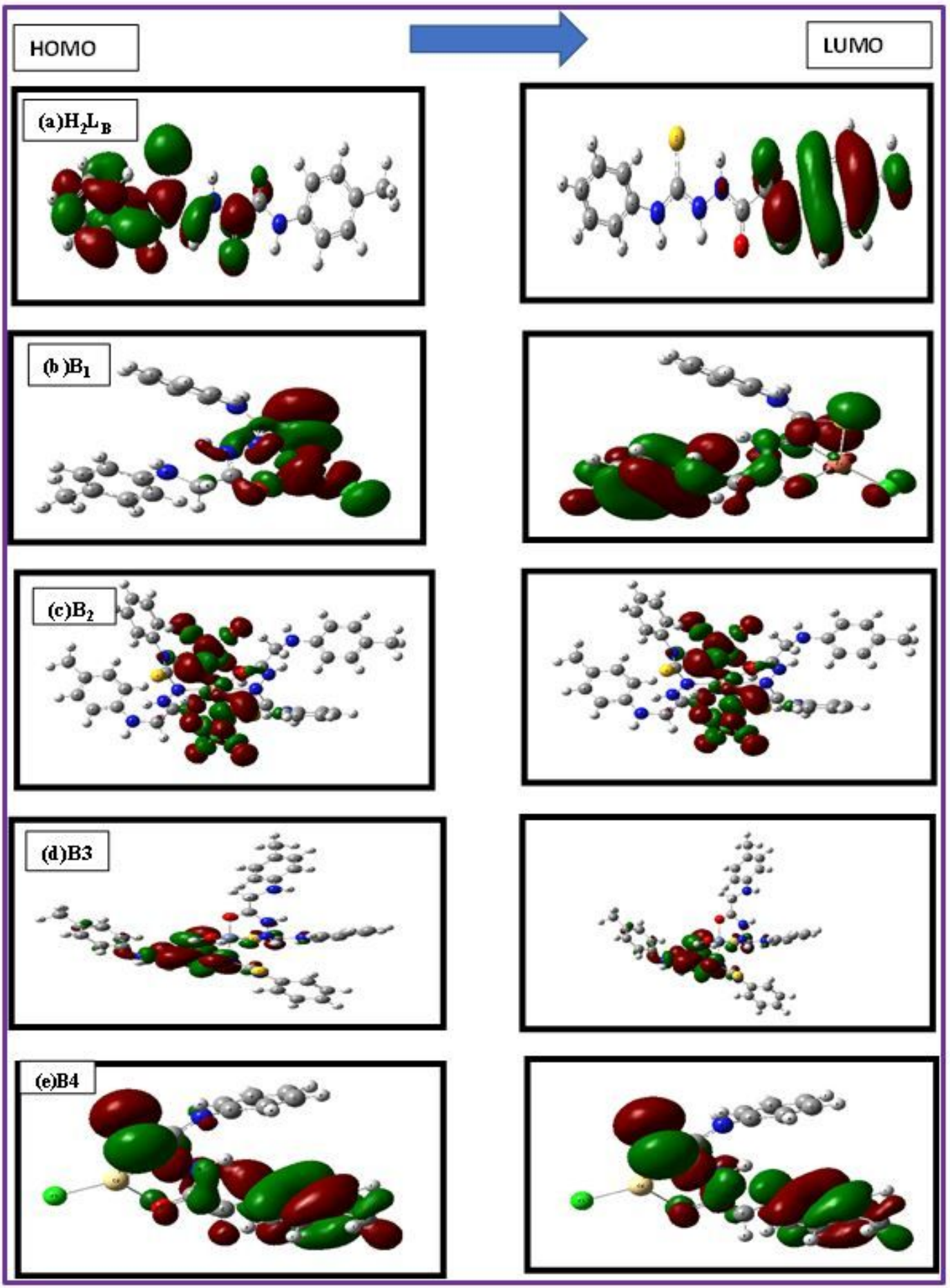

Figure 22

Frontier HOMO and LUMO molecular orbitals for ligand (a) H2LB, (b) B1= [Cu(H2L)I], (c) B2= [Cu(H2L)2ClO4], (d) $\mathrm{B} 3=[\mathrm{Zn}(\mathrm{H} 2 \mathrm{~L}) 2 \mathrm{ClO} 4]$ and $(\mathrm{e}) \mathrm{B} 4=[\mathrm{Cd}(\mathrm{H} 2 \mathrm{~L}) \mathrm{Cl}] \mathrm{Cl}$ complexes calculated at DFT level. 


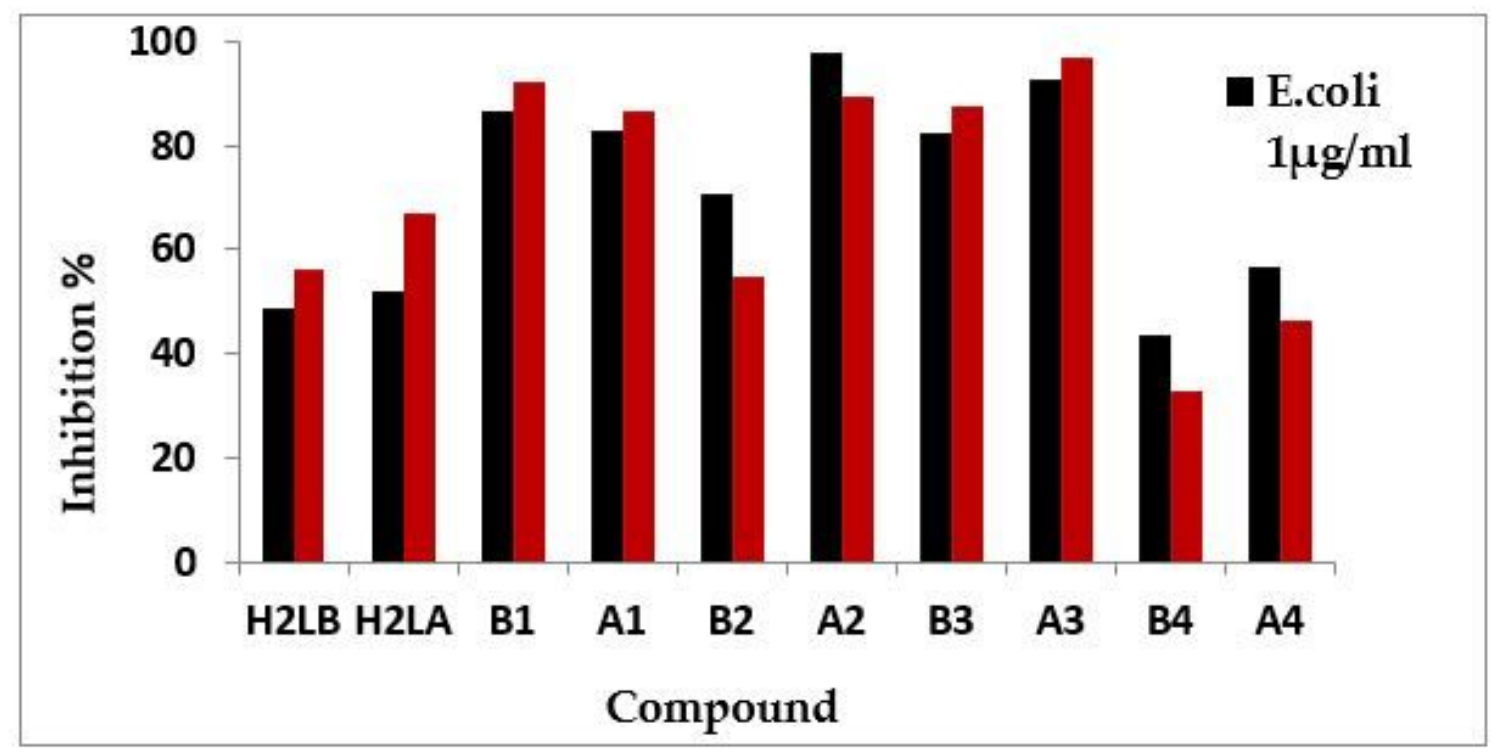

Figure 23

Antibacterial activity for ligand and copper, zinc and cadium (B1, B2,B3,B4 and A1,A2,A3, A4) complexes before and after irradiation against E. coli

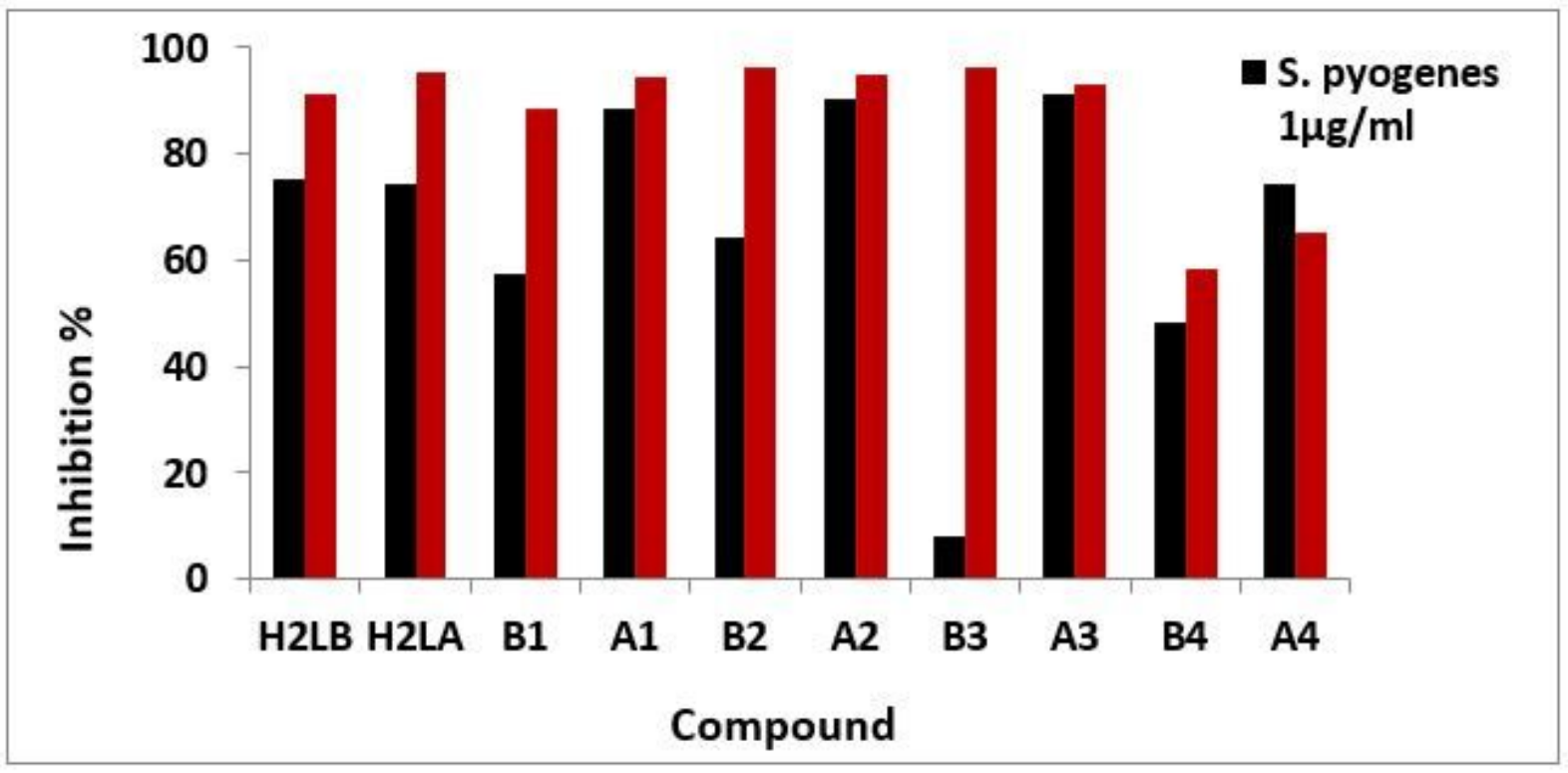

Figure 24

Antibacterial activity for ligand and copper, zinc and cadium (B1, B2,B3, B4 and A1,A2,A3, A4) complexes before and after irradiation against $S$. pyogenes 

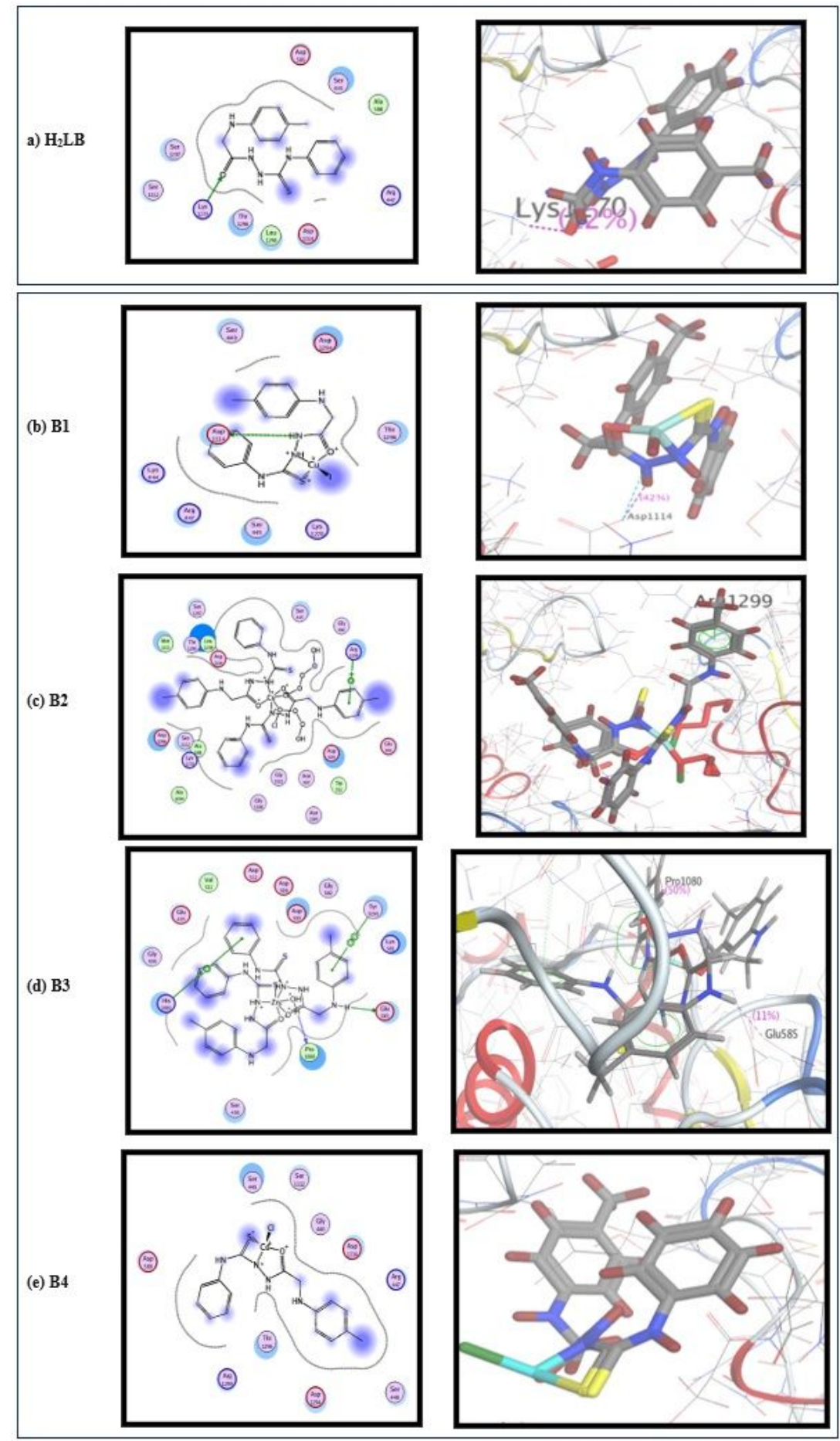

Figure 25

Binding pose of a) $\mathrm{H} 2 \mathrm{LB}, \mathrm{b})[\mathrm{Cu}(\mathrm{H} 2 \mathrm{~L}) \mathrm{I}$, c) [Cu(H2L)2(ClO4)2],d) [ $\mathrm{Zn}(\mathrm{H} 2 \mathrm{~L}) 2(\mathrm{H} 2 \mathrm{O})] \mathrm{SO} 4$ and e) [Cd(H2L)Cl]Cl complexes in the active pocket of topoisomerase II DNA gyrase enzymes (PDB ID: 2XCT).

\section{Supplementary Files}

This is a list of supplementary files associated with this preprint. Click to download.

- scheme1.jpg 